\title{
Guano-derived morphologies and associated minerals in Cova de sa Guitarreta, Llucmajor, Balearic Islands
}

\author{
Antoni Merino (D ${ }^{1 *}$, Joan J. Fornós (D) 1,2, Antoni Mulet (D) ${ }^{3}$, and Joaquín Ginés (D) 1,2 \\ ${ }^{1}$ Earth Sciences Research Group, Universitat de les Illes Balears, Crta. Valldemossa km 7.5, 07122 Palma, Mallorca \\ ${ }^{2}$ Societat Espeleològica Balear, Carrer Margarida Xirgu, 16, 07011 Palma, Mallorca \\ ${ }^{3}$ Federació Balear d'Espeleologia, Passeig Uruguai, s/n, 1, izq. Velódromo Palma Arena, 07010 Palma, Mallorca
}

\begin{abstract}
Cova de sa Guitarreta is located in the southern part of Mallorca Island (western Mediterranean). It was formed presumably by hypogenic processes in Upper Miocene reefal calcarenites. The cave hosts an important breeding bat colony during the end of spring and early summer. Its microclimate is influenced by the presence of a thermal water phreatic pool $\left(27.7^{\circ} \mathrm{C}\right)$ and by the bat population residing in cave during the reproductive season. The morphological bat-related features include bat claws and thumb marks scratches, along with several others linked to bat excreta and aggressive leachates from guano. From a mineralogical point of view, the cave hosts a remarkable cave mineral association linked to guano; among the nine phosphates identified, three of them are reported for the first time in Mallorcan caves (newberyite, struvite, and whitlockite). Particularly interesting is the dichotomy between struvite and newberyite: the first one occurs when the cave is occupied by bat colonies (spring-summer), whereas during the colder seasons, the transformation of metastable struvite into the more stable newberyite occurs. Caves with seasonal cyclical occupation of bat colonies could provide a new field for the study of guano-related mineral assemblages.
\end{abstract}

Keywords: $\quad$ Bats, guano, phosphates, $\mathrm{pH}$, microclimate, newberyite, struvite

Received 13 December 2021; Revised 21 January 2022; Accepted 25 January 2022

Citation: Merino, A., Fornós, J.J., Mulet, A., Ginés, J., 2022. Guano-derived morphologies and associated minerals in Cova de sa Guitarreta, Llucmajor, Balearic Islands. International Journal of Speleology, 51(1), 43-58. https://doi.org/10.5038/1827-806X.51.1.2410

\section{INTRODUCTION}

Although the investigation of biologically-induced erosion processes in karst settings accounts for an extensive literature, mainly devoted to surface processes (see references in Viles, 1984), the interest on the morphogenetic role of bats in caves is relatively recent, as it is evidenced by several outstanding papers (Audra et al., 2016; Barriquand et al., 2021). These more or less recent contributions focus on several different aspects: the morphogenetic impacts of bat populations (Lundberg \& McFarlane, 2008; Dandurand et al., 2019), the mineralization associated to guano accumulations (Onac et al., 2002; Onac \& Veres, 2003; Giurgiu \& Tămaş, 2013; McFarlane \& Lundberg, 2018; Audra et al., 2019, 2021), or the microclimate conditioned by bat colonies (Lundberg 8 McFarlane, 2015), among other topics.

In Mallorca Island, morphogenetic issues associated to bats presence, received little attention to date. Worth mentioning are two preliminary studies on cave minerals that include some guano-related mineral species (Onac et al., 2005) and, more recently, an extensive paper on the morphological and mineralogical data on the ancient bat presence in Cova des Pas de Vallgornera (Merino et al., 2019).

The aim of the present paper is to contribute knowledge on bat-related phenomena, while providing new morphological, mineralogical and climatic data obtained from a cave in Mallorca Island (western Mediterranean) that seasonally hosts an important bat colony. The focus is on biomechanical erosion and other features related to bats and, particularly, on mineral assemblages linked to guano accumulations that show some kind of seasonal occurrence.

\section{COVA DE SA GUITARRETA: GENERAL SETTING}

The investigated cave is situated in the municipality of Llucmajor (Fig. 1) and opens on a carbonate platform that stretches along the southern area of Mallorca Island. It is excavated in flat lying reefal calcarenites of Upper Miocene age (Ginés et al., 2017), located about $5 \mathrm{~km}$ to the south of the Païssa geothermal manifestations site (López \& Mateos, 
2006; López, 2007). Regarding its morphology, Cova de sa Guitarreta is formed by a short subvertical pit that gives access to a steep slope which communicates with a medium-size collapse chamber, $20 \mathrm{~m}$ in diameter and about $10 \mathrm{~m}$ in height, with its floor covered in boulders. Heading to the south-west of the main room, a small hole shows the way to a short climb down that leads to a series of constricted crawls through an inclined labyrinth of collapsed calcarenite boulders (Bermejo et al., 2021). At the bottom of it, the water table is reached at a depth of $58 \mathrm{~m}$, presenting an anomalous warm temperature of $27.7^{\circ} \mathrm{C}$; the average annual temperature of the area is $\sim 18^{\circ} \mathrm{C}$ (López, 2007). This fact, as well as other cave morphologies, point out towards a hypogene origin for the cave (Ginés \& Ginés, 2009; Ginés et al., 2017; Merino et al., 2011). This high temperature causes a thermal gradient between the warm and humid air that ascends from the pools formed by the phreatic waters and the walls and ceiling of the chamber, that present a lower temperature due to their proximity to the surface. In addition, during the colder months, a "stream" of cool air descends to the lowest part of the chamber causing, 1) a cool air layer on the floor, and 2) generating a flow of cool air that penetrates down to the bottom of the cave (phreatic water table), which in turn, causes the warm and humid air to rise to the upper chamber. This air reaches the main chamber through the accumulation of boulders that surrounds its western sector.

The cave houses a medium-size insectivorous bat maternity colony whose fluctuating population has never been rigorously assessed but could be estimated, depending on the year, in between 500 and 150 individuals (Balcells, 1968; Alcover \& Muntaner,
1986). The colony is formed mainly by two species of bats: Myotis myotis (which represent approximately $53 \%$ of the total) and Miniopterus schreibersii (40\%) as well as some Myotis capaccinii (7\%) (Serra-Cobo et al., 2006, 2007). In the past, there has also been reported the presence of sporadic Rhinolophus hipposideros and Rhinolophus mehelyi (Ginés, 1982), the latter representing a thermophilic species. The colony roosts and occupies the cave between April and August (Serra-Cobo et al., 2011).

The breeding clusters are located mainly on the roof of the chamber, but we have also identified two small roosting spots on the tight fissure that connects with the deepest part of the cave. During the reproduction period, these locations show warm and stable temperature conditions, away from external influences, providing the preferred breeding-roosting sites. However, this warm environment would have acted as a deterrent for bats to hibernate in the cave (Tuttle, 1975; Ransome, 1990; Lundberg \& McFarlane, 2008). The cave has undergone important changes caused by bat ethology and their production of guano and urine. Biomechanical erosion originated by bats is responsible for the alteration of cave walls and ceiling when bats use their claws and thumbs, giving rise to specific morphologies. Bat droppings accumulations and urine provoke biochemical alteration inducing the formation of distinct features on the rock surface. At the same time, degradation of guano deposits leads to the production of acidic leachates, which in turn, react with sediments and host-rock, precipitating a variety of minerals, mainly phosphates.

To reduce disturbances to the bat colony, the research project was executed mostly during the period of the year when bats are not in the cave.

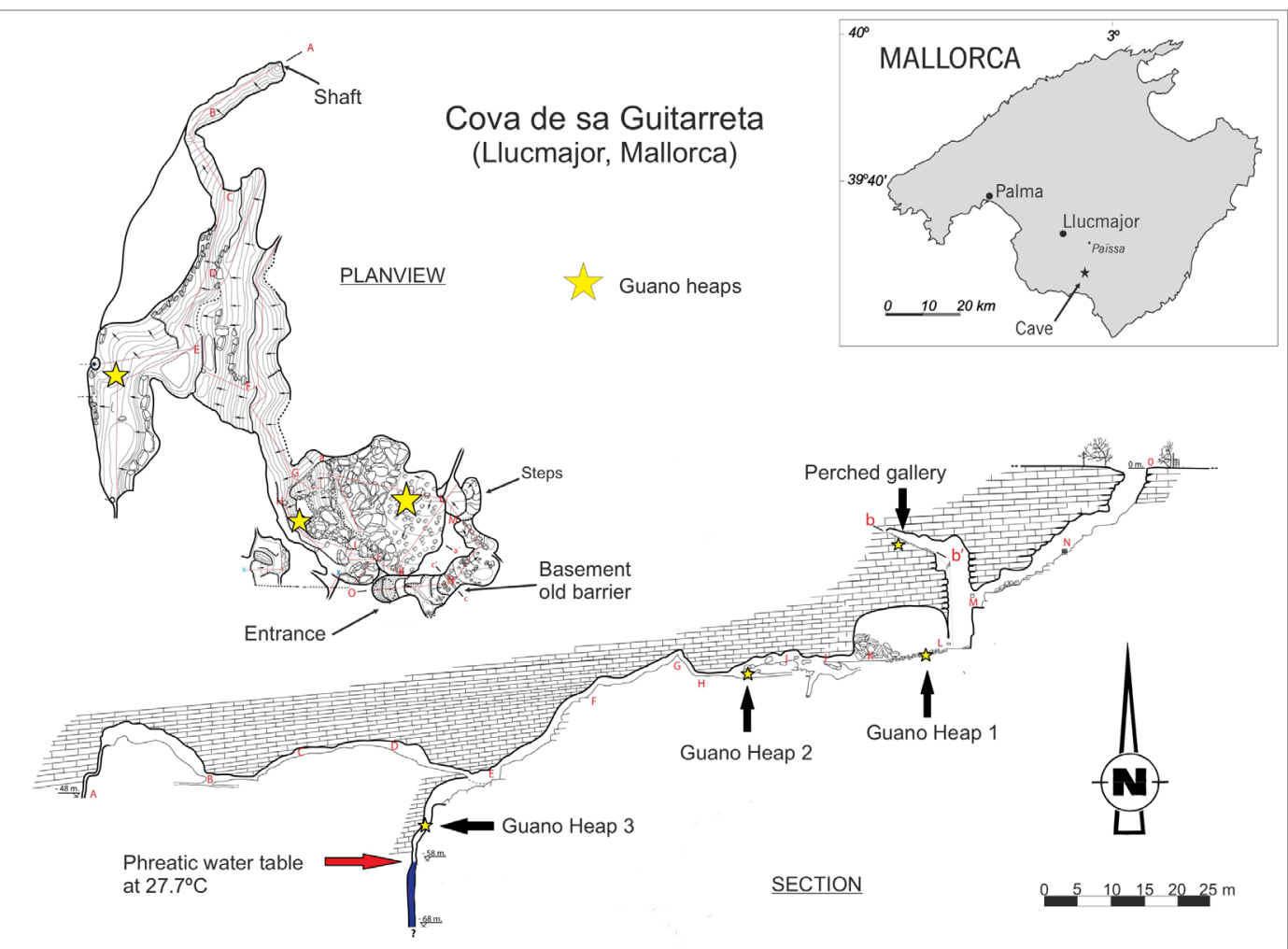

Fig. 1. Survey of the cave, showing the locations of guano heaps (modified, with permission, from the original survey performed in 2020 by J. Bermejo, J.V. Pardo, G. Mulet, and B. López, Grup Espeleo de Llubí - GELL; Bermejo et al., 2021). 


\section{METHODS}

For this research project, 74 samples of guano and mineral deposits were collected from scattered and selected sites throughout the cave, as well as from three guano heaps situated at different locations between the chamber and the bottom of the cave (Fig. 1). A guano core was extracted from the main mound, for the purpose of achieving a representative and undisturbed sample; a $5 \mathrm{~cm}$ diameter PVC tube, with one of its tips sharpened, was used to gently penetrate the pile of guano.

Chemical, mineralogical, and physical environmental parameters were measured both in samples and in the cave. The $\mathrm{pH}$ was determined on a homogenized (for one minute) suspension of one part of guano and 5 parts distilled-deionized water, using a $\mathrm{pH} 70$ portable meter (XS Instruments), previously calibrated with buffer solutions at $\mathrm{pH} 4$ and $\mathrm{pH} 7$.

Temperature was measured using a Hanna HI9060 device equipped with a $1 \mathrm{~m}$-long probe. $\mathrm{CO}_{2}$ and relative humidity $(\mathrm{RH})$ were determined operating a calibrated AZ77535 instrument from AZ Instruments Corp.

Mineralogy was determined using a Bruker D8Advance X-ray diffractometer on randomly oriented powders of the bulk samples. The pressed powder diffraction patterns were recorded from $3^{\circ}$ to $65^{\circ} 2 \theta$ in steps of $0.03^{\circ}, 0.3$-s counting time per step, at $25^{\circ} \mathrm{C}$ room temperature, and logged to data files for analysis. Semi-quantitative mineral analyses were based on the peak areas obtained using Diffrac EVA ver.7.0 software. Selected samples were observed on a Hitachi S-3400N scanning electron microscope (SEM) equipped with a Bruker energy-dispersive X-ray analysis system (X-Flash Detector 4020).

Bell holes dimensions were also measured. Because the roof of the chamber is high and inaccessible, obtaining dimensional data was restricted to those bell holes that could be measured using a Leica DISTO laser. The instrument was mounted on a tripod directly below them, taking the height of the ceiling at its lip and the height of the bell hole at its center. Width at the lip was measured using a small drone equipped with a scale. The device was flown below the bell hole and kept still as close as possible to its base; then several photos were taken from an elevated position (Fig. 2). For obvious reasons, the measures are estimated, but provide useful data on these extremely scarce morphologies in Mallorca.

In order to unveil the areas with higher temperatures within the cave, a HTO2 handheld thermograph camera (measuring accuracy $\pm 2 \%$, thermal sensitivity $0.5^{\circ} \mathrm{C}$ ) from General Tools and Instruments was utilized.

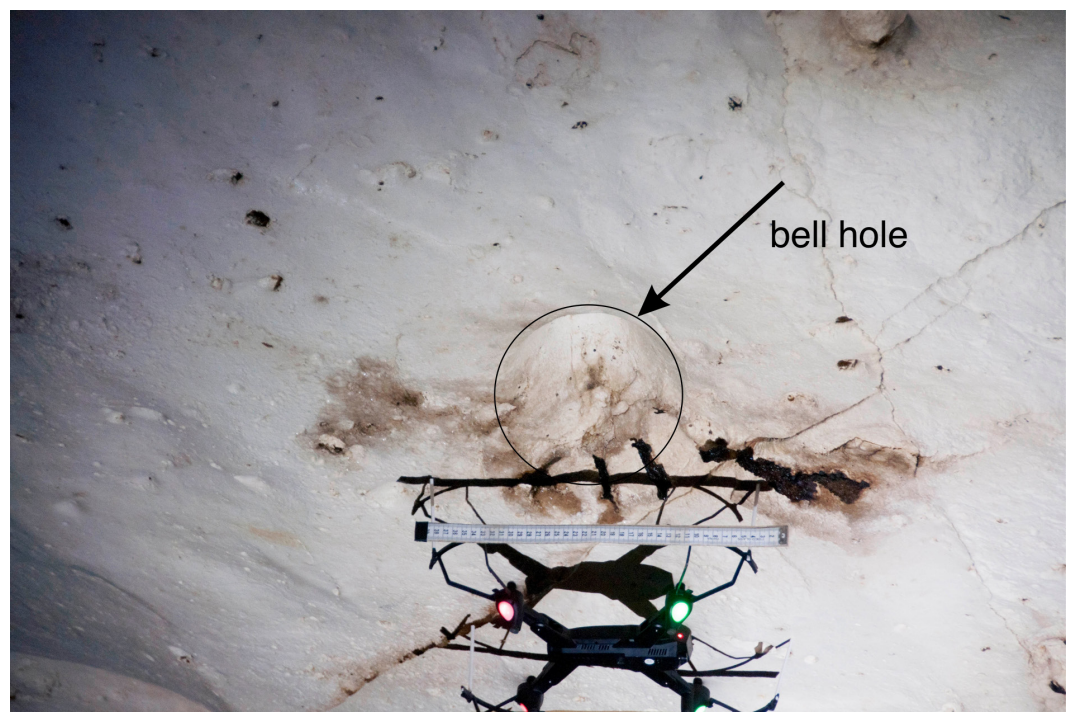

Fig. 2. Small drone with a mounted centimeter scale positioned just below a bell hole, about $10 \mathrm{~m}$ above the floor of the chamber. Dark trickles and brown surfaces are clearly visible.

\section{DESCRIPTION OF BAT-ASSOCIATED MORPHOLOGIES}

The bat-related features present in Covade sa Guitarreta can be categorized into two groups, depending on how the alteration agent acts and its effect on carbonate rock: (1) morphologies caused by biomechanical erosion present on walls, boulders, and roof and (2) specific features related to guano accumulation.

\section{Biomechanical erosion}

These peculiar morphologies, identified as bat scratches, were first described in detail by Merino et al. (2019) and can be divided into bat claws and bat thumb marks.

\section{Bat claws and thumbs marks}

These almost inconspicuous morphologies are widely present in the cave, mainly on the walls of the main chamber and even on the boulders accumulated on its floor. They have also been spotted on the walls of a tight rift that leads to the deepest part of the cave. Depending on how bats try to cling to the rock, the following two types of marks can be distinguished: bat claws and bat thumbs. The first one shows an assemblage of quite parallel grooves carved in the bedrock, whose number can fluctuate between two and five, and having irregular length, from a few centimeters up to $17 \mathrm{~cm}$ and less than one millimeter in depth (Fig. 3a, c). On rare occasions it is possible to distinguish $\mathrm{V}$-shaped marks 
produced by the same individual when trying to hang using both feet claws. The marks left by bat thumbs (Fig. 3b) are not abundant and show a single uneven groove of different length and with a depth of less than one millimeter. As it happens in Cova des Pas de Vallgornera (Merino et al., 2019), marks are more visible when affect a weathered rock surface that exhibits difference in color. When these indentations have been produced on an unaltered surface, like fresh host rock or boulder surface exposed after a collapse episode, they are rather difficult to distinguish even when covering a large area (Fig. 3d). Claw marks can be found as low as at the bottom of the walls that surround the lowest area of the chamber, and up to the ceiling. Moreover, one isolated spot with marks has been observed on walls and boulders around Heap 3 at a depth of $55 \mathrm{~m}$, near the water table (Fig. 1). At this site, most of the boulders are covered by a thin light-brown altered crust that shows profusely decorated surfaces with marks of both types. At some locations, grooves are so plentiful that they erode deeply the surface.

\section{Description of features related to guano deposits and bat excreta}

\section{Dark trickles and brownish surfaces}

The most evident and visible features related to the current presence of bats are dark trickles and brownish surfaces (Fig. 4a). The former occurs as brown to black staining spots that cover small areas on the walls and the ceiling of the chamber. These blackish dribbles descend along the walls following the lines of steepest slope. They are caused mostly by aggressive seepage originated by the influence of bat individuals or small groups when excreting while roosting. The latter, brownish surfaces, cover significant areas, commonly on the ceiling; this dark-colored feature extends along several square meters, being clearly delineated by the sharp contrast between the white calcarenite bedrock and the colored crust. These morphologies represent the by-product of bedrock alteration caused by organic processes mainly related to excreta of bats, being made up of phosphates (Lundberg \& McFarlane., 2008; Audra et al., 2016).
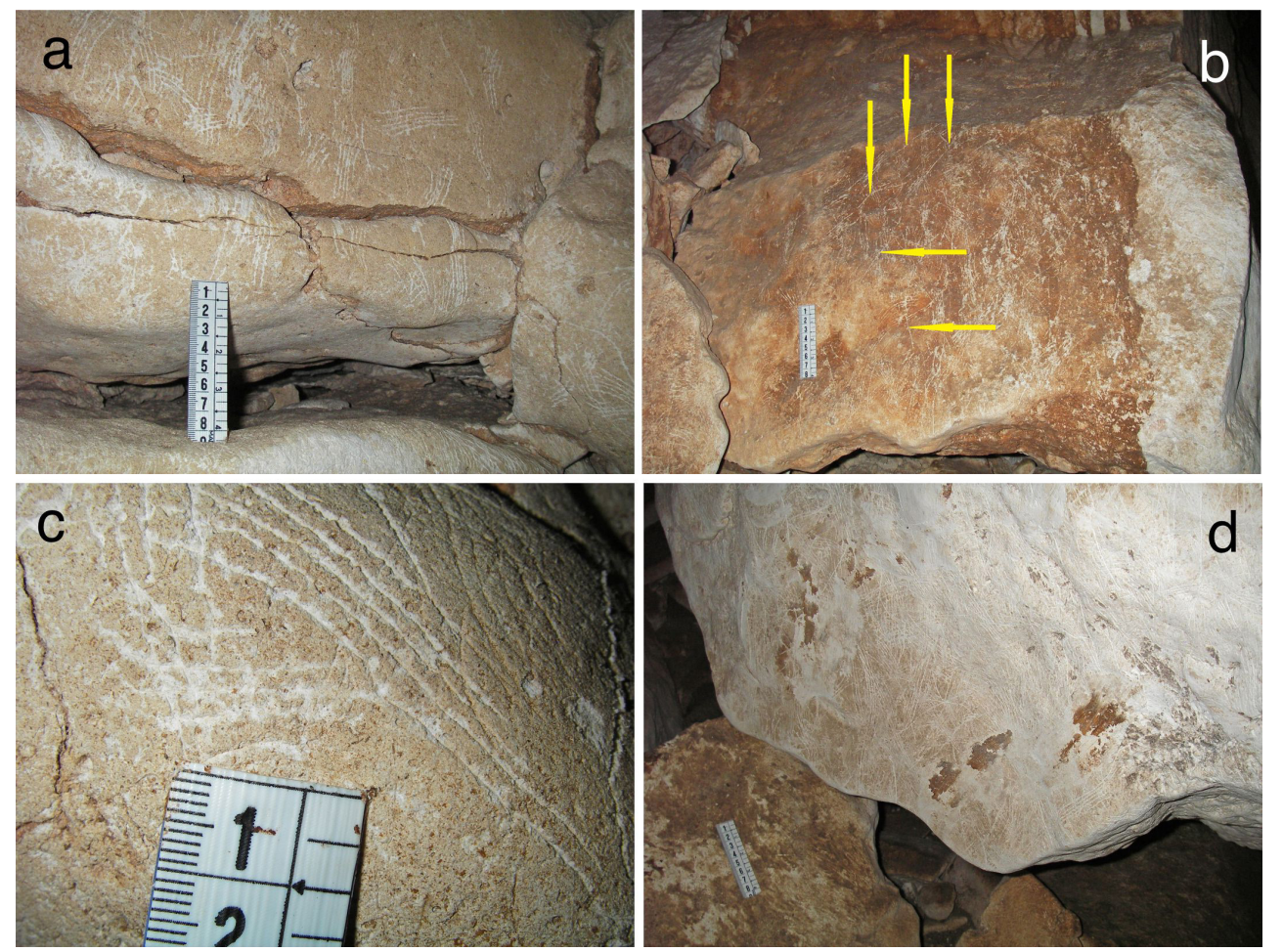

Fig. 3. a) Assemblage of bat claws marks covering a wall. To the right of the photo it can be noticed how powerful the traction exerted by bats is while trying to cling to the wall: the claw marks start above a fissure going downwards crossing it and extending below; b) A great deal of bat scratches affecting a falling boulder located at the chamber. Bat thumb marks intermingled with claw marks; arrows show their positions. Scale in centimeters; c) Bat claw marks left on the bedrock in detail, grooves are about one millimeter in depth; d) Comparison between two areas covered in bat scratches. The one to the left presents an altered light brownish surface with obvious marks, while the white one to the upper right corner shows inconspicuous marks, difficult to be distinguished.

Most of the limestone blocks that floor the main chamber are covered by thin coatings of dark-brown to black relatively fresh guano, whereas others are overlaid by less homogeneous grey blanket of old and decomposed guano. The areas of fresh or more recent guano correspond to sections of walls and ceiling that exhibit abundant dark trickles and brownish surfaces, whilst the powdery grey, old guano zones coincide with cleaner wall and roof sections. This indicates that the bat-clusters change their locations, and the subtle weathering of the rock surfaces blur these morphologies.

\section{Crypto-corrosion features}

Gutter-shaped morphologies have been identified on two massive boulders located at the north-western flank of the chamber. They occur as smooth channels that develop from the top of an inclined substrate; at the same time some small bowl-shaped pits are also present (Fig. 4b). These resembling rinnenkarren features have been formed under the guano surface by organic acid dissolution of carbonate rocks in close contact with guano deposits (Audra et al., 2016). Many fallen rocks are partially covered by grayish to 
ochre crusts composed of a mixture of hydroxylapatite and whitlockite (Fig. 4c), under which small pockets and indentations occur.

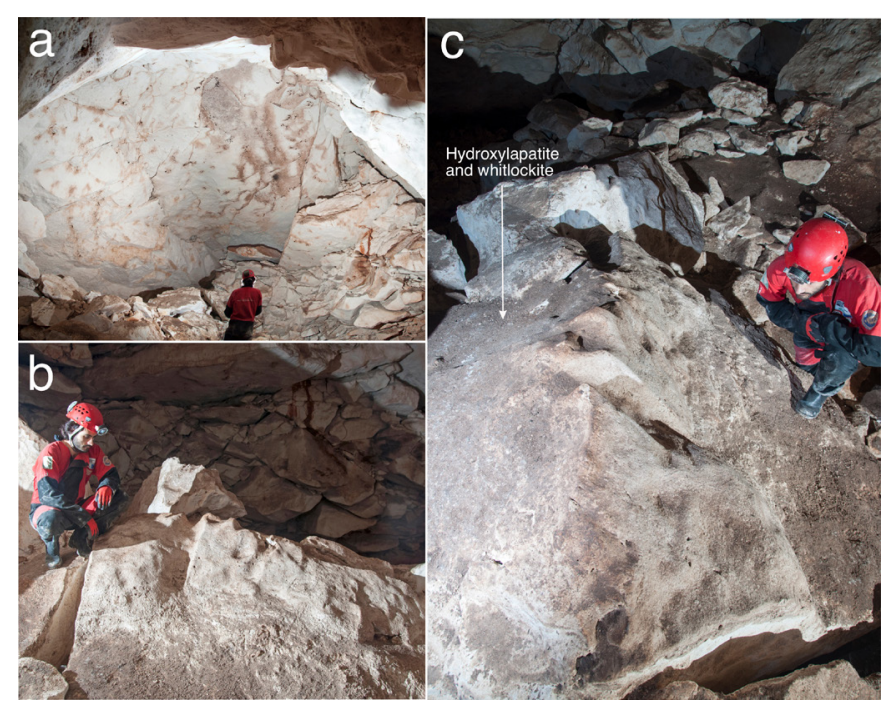

Fig. 4. a) General perspective of the main chamber of Cova de sa Guitarreta. Abundant dark trickles and brown surfaces can be clearly seen on the ceiling, while a large accumulation of boulders form the lower third of the chamber; b) Massive boulder exhibiting guttershaped morphologies and small concave surfaces caused by guano accumulations; c) Grayish pastry crust formed by a mixture of hydroxylapatite and whitlockite overlaying a boulder that also shows cryptocorrosion features.

\section{Bell holes}

Bell holes are not abundant in the cave, being only present in the central roof area of the chamber. Two of them were measured showing modest sizes; the first one has an open bell shape, with a diameter (W) of $17.5 \mathrm{~cm}$, and $10 \mathrm{~cm}$ in depth (D). The second one, shows a more cylindrical configuration, being 12.35 $\mathrm{cm}$ in diameter and $7 \mathrm{~cm}$ in depth, both exhibiting stains from their lips, and the largest one presents dark-colored crusts as well (Fig. 5a), probably dark trickles. These results issue a $\mathrm{W} / \mathrm{D}$ ratio of 1.75 and 1.76 respectively, which would be in the higher values of the ratio statistics published by Lundberg and McFarlane (2008).

\section{Asymmetrical cavities}

Despite of the bell holes scarcity, there are a wealth of irregular voids distributed throughout the cave. This concave open morphology is quite variable in size, displaying an elongated shape, with an uneven stained surface that shows small irregular voids (Fig. $5 b)$. The brown colored crust is composed mainly of hydroxylapatite, with whitlockite also present in some occurrences. They develop mainly on walls, overhangs, and boulders on which small clusters of bats hang while roosting or breeding. Obviously, this wideopen configuration does not allow the accumulation of aggressive moisture ultimately responsible for the development of bell holes. On the contrary, at these spots $\mathrm{CO}_{2}$ and water vapor produced by bats metabolic processes escape to the cave atmosphere, preventing the condensation corrosion process from happening. Therefore, the genesis of this morphology could be related to bat urine jets and to a lesser extend to faeces, since the inclined surfaces where they form would reduce the physical problem of upward dissemination of bat excreta. Simultaneously, these features would concentrate bat droppings on certain sites below them, where guano pots would occur.

In the deepest section of the cave, the Upper Miocene bedrock walls exhibit surfaces with abundant voids that have been used as small alcove-shaped shelters, about $11 \mathrm{~cm}$ in height, $6 \mathrm{~cm}$ in width, and $8 \mathrm{~cm}$ deep (Fig. 5c). The floor of these alcoves is covered with guano deposits and brown stains consisting of hydroxylapatite. This quite closed configuration would have promoted condensation corrosion processes, which in combination with the dissolution caused by bat urine and guano, would have extend the initial voids.

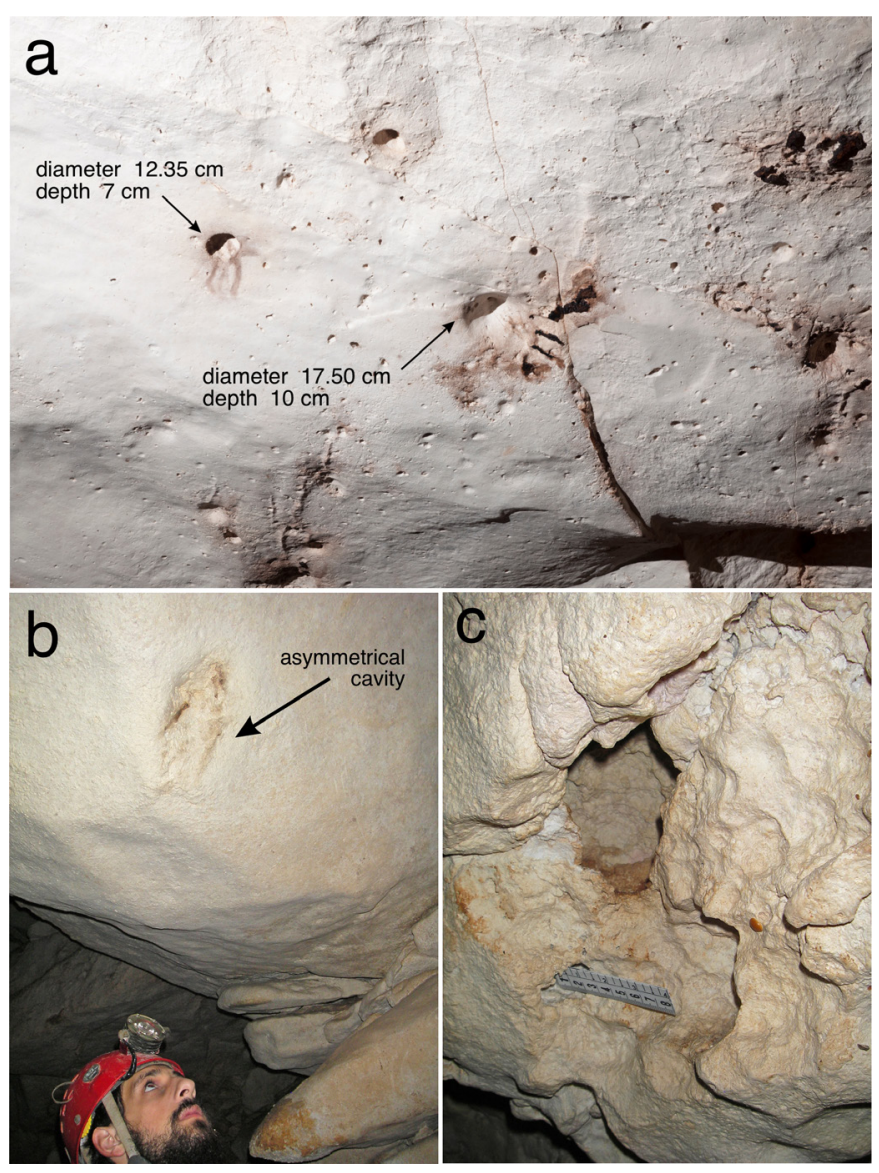

Fig. 5. a) Group of small bell holes, with their dimensions, located in the ceiling of the chamber. Dark trickles and brown dribbles are noticeably seen spreading out from their lips; b) Asymmetrical cavity showing an uneven surface with small irregular voids. The dark brown dribbles are composed of hydroxylapatite; c) Alcove-shaped shelter located at the deepest sector of the cave; the brown crust that floors the void is mainly formed by hydroxylapatite. Scale in $\mathrm{cm}$.

\section{Guano pots}

As noted above, asymmetrical cavities are abundant, most of them present the corresponding guano pot (Audra et al., 2016) just below (Fig. 6a). Their genesis is a consequence of the accumulation of bat faeces on the bedrock, where corrosion takes place under the guano surface at the rock-guano interface, etching out this feature. Guano pots are coated with a grey to brown layer of hydroxylapatite. They develop on the decomposed and fractured rock area that raises towards the northern section of the chamber. When this morphology develops on a horizontal surface, normally a boulder, displays a shallow bowl shape that is $\sim 20 \mathrm{~cm}$ in diameter 
and a depth between 4 and $2 \mathrm{~cm}$ (Fig. 6b). Instead, when guano pots originate on a truncated or steep surface, commonly wall bedrock or tilted boulders, then this feature shows an open configuration with a funnel-shaped upper section and a more cylindrical lower part (Fig. 6c). Dimensions of this morphology can range up to $35 \mathrm{~cm}$ in diameter and a depth of $48 \mathrm{~cm}$.

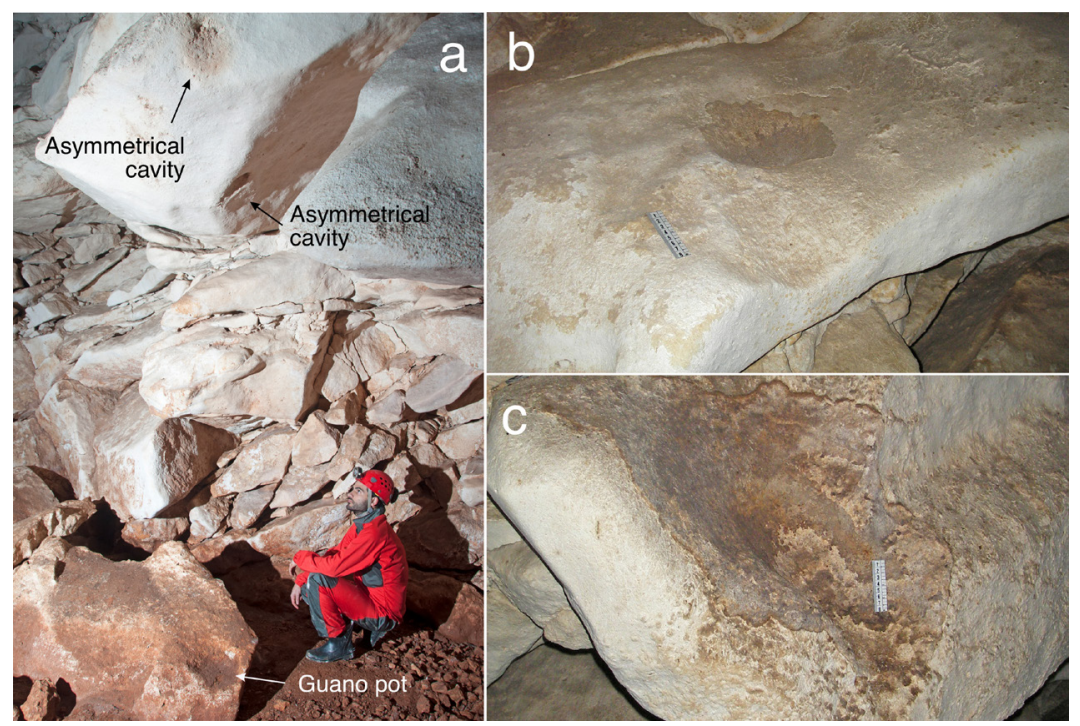

Fig. 6. a) Assemblage of an asymmetrical cavity and its corresponding guano pot, just below it. At the top of the photo another extensive asymmetrical cavity is visible, exhibiting the common stained surface; b) Guano pot originated on a fallen tabular rock; the brown crust is composed of hydroxylapatite. Scale in $\mathrm{cm}$; c) Guano pot developed on a sheer surface, with brown layers of phosphates covering its surface. Scale in $\mathrm{cm}$.

\section{Weathered walls}

This feature was identified on an overhanging wall, at $\sim 32 \mathrm{~m}$ in depth, just above Heap 2 (Fig. 7). The inclined wall exhibits elongated black to brown crusts and dark trickles, that extend from the sloped plane to the more vertical wall below. The crusts, formed by a combination of hydroxylapatite and whitlockite, protrude up to $2 \mathrm{~cm}$ from the wall whose surface shows a distinct white to light brown color and small concavities excavated on it. Simultaneously, wide dark trickles of hydroxylapatite, can also be observed below the crusts. As mentioned before, the most affected area is an overhanging wall; this could be explained, as in the case of asymmetrical cavities, by the physical position of bats hung to the wall and the projection of guano and urine.

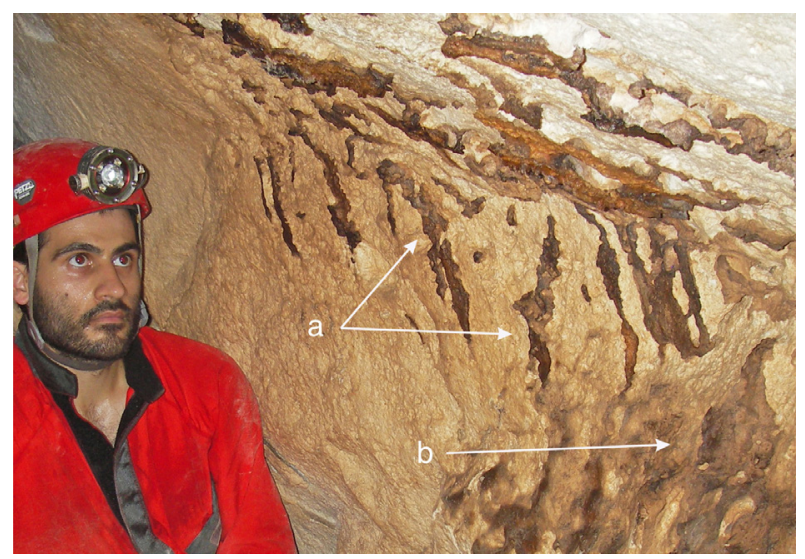

Fig. 7. Weathered overhanging wall situated below the bottom of the main chamber. Long black to brown crusts, formed by hydroxylapatite and whitlockite, protruding from the altered wall can be distinguished in the upper section of the photo (a). At the same time, extensive brown layers composed of hydroxylapatite are observed to the right of the image (b).

\section{Pupal deposition of bat flies}

Although little is known about the impact of the reproduction of bat parasites on wall biocorrosion, this cannot utterly be ruled out. During procreation, pupae belonging to Nycteribiidae and Streblidea ectoparasites are deposited in or close to the bat roosting sites (Dittmar et al., 2009). In doing so, pupae are attached to the cave wall where a chemical reaction starts between the chitin, which progressively solidifies, and the limestone that forms the cave wall, resulting in a hard and black shell (Rahman et al., 2019; Barriquand et al., 2021). Over time, the role of this bio-mineralization process could cause a micro-corrosive trace on the cave walls. In the ceiling of the main chamber of Cova de sa Guitarreta, important accumulation of pupae has been observed surrounding the swarms that constitute the main bat cluster. In addition, some scattered unhatched and hatched pupae have also been identified on the westside wall where they are oval in shape, whereas the average length is about $3 \mathrm{~mm}$ (Fig. 8).

\section{GUANO ACCUMULATIONS}

Apart from the already known guano deposit located in the main chamber, three new guano locations have been discovered, two of them between the chamber and the bottom of the cave, and a third one located in a perched gallery at the top of the chimney above the main chamber (Bermejo, pers. comm.) (Fig. 1). The first and already known largest guano accumulation (Heap 1) is located in the main chamber and covers several square meters (Fig. 9a). It is composed of a flat guano mound, of irregular thickness, which contains abundant embedded 
fragments of rocks. The second one, Heap 2, is a small mass situated $\sim 5 \mathrm{~m}$ below the floor of the main chamber, at a steeply tight passage. Finally, the third guano deposit (Heap 3) is located at a depth of $55 \mathrm{~m}$, close to the phreatic water table, and consists of a guano pile irregularly distributed on a pile of blocks of different sizes (Fig. 9b). Samples have been mainly collected from Heap 1 and 3. Heap 2 has not been completely sampled because it was partially disturbed by passing cavers.

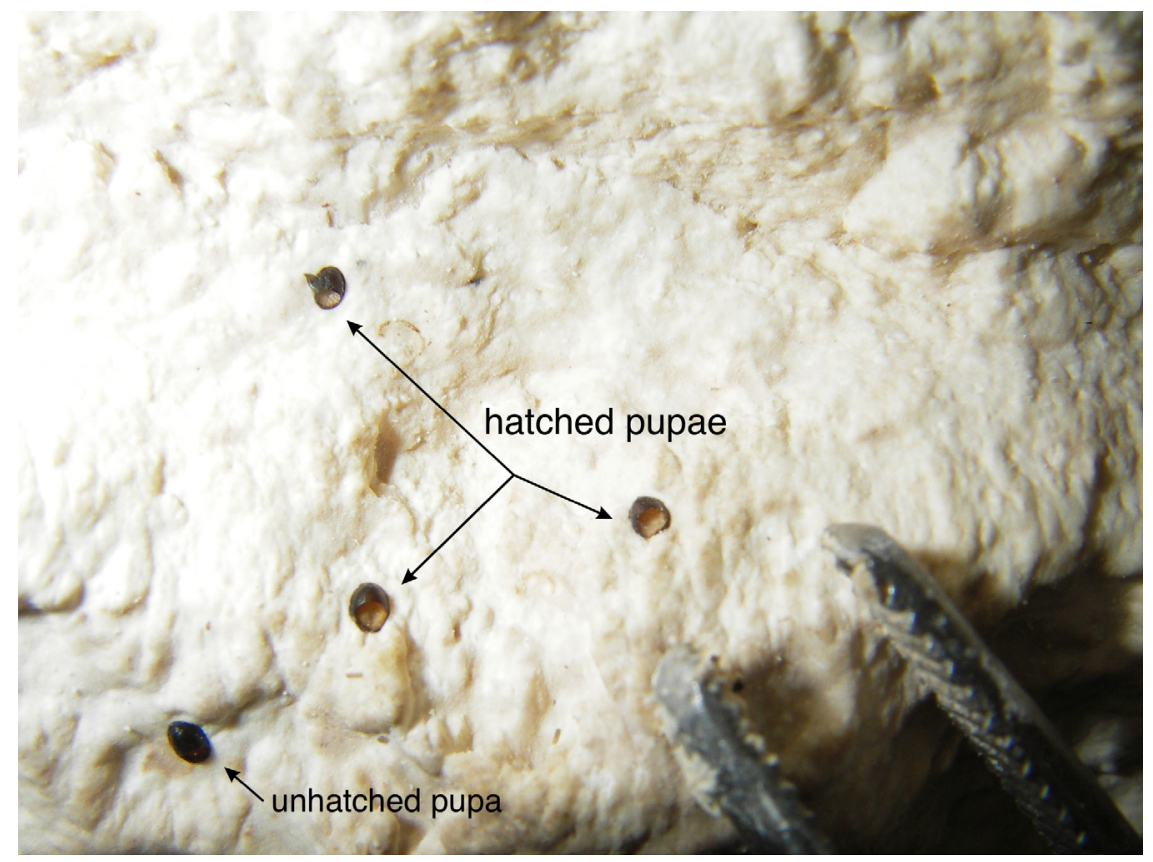

Fig. 8. Black shells of hatched and unhatched pupae located at the west-side wall of the chamber. Length of shell pupa is about $3 \mathrm{~mm}$.
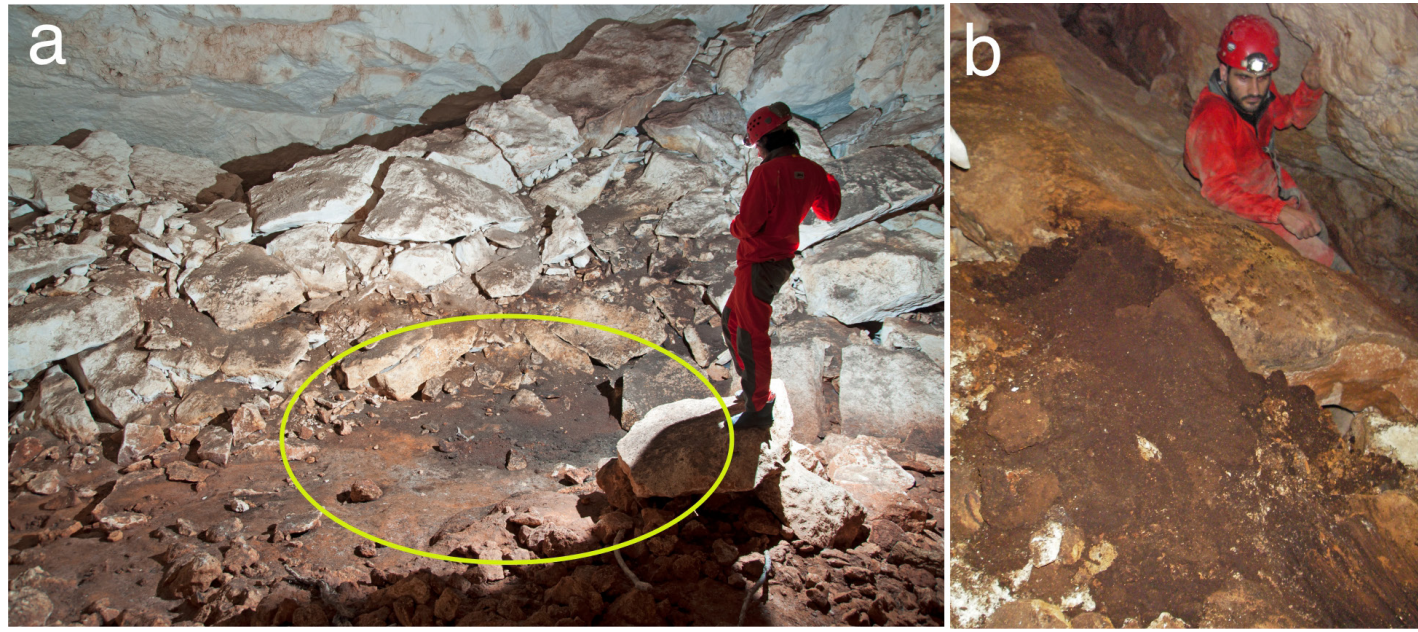

Fig. 9. a) Partial view of the main guano accumulation, Heap 1. Scattered guano deposits can be seen covering most of the fallen blocks; b) Irregular guano Heap 3, situated at the bottom of the cave. Between the mound and the caver, a brown-yellowish crust formed mainly by hydroxylapatite covers the limestone boulder.

\section{Guano associated cave minerals}

Some minerals related to guano deposits in Cova de sa Guitarreta were already described by Onac et al. (2005) from samples collected in the peripheral area of the guano accumulation at the main chamber (Heap 1). The following minerals (associated with guano) were identified: gypsum, ardealite, brushite, carbonate hydroxylapatite (now known as hydroxylapatite), collinsite, and taranakite. The paper also stressed the noteworthiness of this cave for displaying one of the most variegated mineralogy on the island. Following a research project carried out in Cova des Pas de Vallgornera in 2018 (Merino et al., 2019) regarding the existence of ancient bat marks on the walls and ceiling of different passages, it was decided to visit and investigate Cova de sa Guitarreta with the objective of identifying and contrasting these peculiar morphologies. Between 2010 and 2012, the cave had also been the focus of a research aimed to relate the discovery of an anomalous, high temperature water in a phreatic pool and its possible effects on speleogenesis, bats, and minerals (Merino et al., 2011).

On this occasion, mineral occurrence (Table 1) has been investigated with the aim of associating their presence with certain morphologies related to old guano deposits and bat excreta. Samples were collected from different sites, mainly related to guanoassociated morphologies present on the upper part of the chamber (away from previously sampled site) and two more locations in the tight rift that leads to the bottom of the cave (Heap 2 and Heap 3). Host rock-linked 
and allochthonous minerals are mainly constituted by dolomite, calcite, quartz, related clay and feldspar minerals as anorthite, illite-group minerals, kaolinite, albite (Na-plagioclase), microcline (K-feldspars), muscovite, orthoclase and montmorillonite. Moreover, a detailed investigation of the mineral association present in fresh and old guano accumulations was carried out (Table 2), along with measurements on the acidity of guano piles.

Table 1. List of phosphate and sulfate minerals identified in Cova de sa Guitarreta $\left({ }^{*}=\right.$ first record in Mallorca).

\begin{tabular}{|l|c|}
\hline \multicolumn{1}{|c|}{ Mineral } & Formula \\
\hline \multicolumn{2}{|c|}{ Pulfates } \\
\hline Gypsum (Gyp) & $\mathrm{Ca}\left(\mathrm{SO}_{4}\right) \cdot 2 \mathrm{H}_{2} \mathrm{O}$ \\
\hline \multicolumn{2}{|c|}{ Phosphates } \\
\hline Ardealite (Ar) & $\mathrm{Ca}_{2}\left(\mathrm{PO}_{3} \mathrm{OH}\right)\left(\mathrm{SO}_{4}\right) \cdot 4 \mathrm{H}_{2} \mathrm{O}$ \\
\hline Brushite $(\mathrm{Br})$ & $\mathrm{Ca}\left(\mathrm{PO}_{3} \mathrm{OH}\right) \cdot 2 \mathrm{H}_{2} \mathrm{O}$ \\
\hline Collinsite (Col) & $\left.\mathrm{Ca}_{2} \mathrm{Mg}_{(\mathrm{PO}}\right)_{2} \cdot 2 \mathrm{H}_{2} \mathrm{O}$ \\
\hline Fluorapatite (Fap) & $\mathrm{Ca}_{5}\left(\mathrm{PO}_{4}\right)_{3} \mathrm{~F}$ \\
\hline Hydroxylapatite $(\mathrm{Hp})$ & $\mathrm{Ca}_{5}\left(\mathrm{PO}_{4}\right)_{3} \mathrm{OH}$ \\
\hline Newberyite* & $\mathrm{Mg}^{*}\left(\mathrm{PO}_{3} \mathrm{OH}\right) \cdot 3 \mathrm{H}_{2} \mathrm{O}$ \\
\hline Struvite* & $\left(\mathrm{NH}_{4}\right) \mathrm{Mg}_{2}\left(\mathrm{PO}_{4}\right) \cdot 6 \mathrm{H}_{2} \mathrm{O}$ \\
\hline Taranakite (Tar) & $\mathrm{K}_{3} \mathrm{Al}_{5}\left(\mathrm{PO}_{3} \mathrm{OH}\right)_{6}\left(\mathrm{PO}_{4}\right)_{2} \cdot 18 \mathrm{H}_{2} \mathrm{O}$ \\
\hline Whitlockite* (Whit) & $\mathrm{Ca} \mathrm{Mg}^{*}\left(\mathrm{PO}_{3} \mathrm{OH}\right)\left(\mathrm{PO}_{4}\right)_{6}$ \\
\hline
\end{tabular}

\section{Prospecting pits description}

Two specific campaigns were conducted to investigate the main guano deposit, Heap 1, in different seasons (winter and summer). Both campaigns were focused on characterizing the mineralization in the guano mound, especially, phosphates and sulfates that occur at its surface (Table 3). The first one took place between February and March, when the cave had been deprived of bats for more than five months, and consisted of digging 2 prospecting pits and extracting a core. All stratigraphic sequences described below are from top to bottom.

Prospecting pit $1(\sim 11 \mathrm{~cm}$ deep) located towards the edge of the guano accumulation.

Layer 1. Loose, dark brown material formed by organic debris (1 cm thick). The main minerals are brushite and newberyite, accompanied by quartz.

Layer 2. Three $\mathrm{cm}$ thick, more compacted, brown to dark brown organic level. The dominant mineral is brushite, associated with quartz and gypsum.

Layer 3. Brown, consolidated unit containing small organic debris (6 cm thick), with abundant hydroxylapatite.

Layer 4. Yellowish to ochre sticky crust covering the underlying bedrock, about $1 \mathrm{~cm}$ in thickness, formed by fluorapatite. In this layer and layer 3 the main mineral phase coexists with brushite, gypsum, and quartz.

Table 2. Analytical results of samples collected from different sites, mainly related to guano-associated morphologies. An: anorthite; Mcl: microcline.

\begin{tabular}{|c|c|c|c|c|c|}
\hline Feature & Sample & Mineral & Associated minerals & Color & Location \\
\hline Floor & Guit-010 & Collinsite & Hp, Q, Gyp, An & Black & Main chamber \\
\hline Dark trickle & Guit-011 & Hydroxylapatite & Whit & Brown & Main chamber \\
\hline Boulder & Guit-013 & Ardealite & Br, Gyp & Grey & Main chamber \\
\hline Boulder & Guit-014 & Hydroxylapatite & Whit & White & Main chamber \\
\hline Boulder & Guit-015 & Hydroxylapatite & Whit & Black & Main chamber \\
\hline Dark trickle & Guit-017 & Hydroxylapatite & - & Brown & Main chamber \\
\hline Guano pot & Guit-018 & Hydroxylapatite & - & Brown-yellow & Main chamber \\
\hline Guano pot & Guit-019 & Hydroxylapatite & $\mathrm{Q}$ & Brown & Main chamber \\
\hline Guano pot & Guit-021 & Hydroxylapatite & Gyp, Q & Brown & Main chamber \\
\hline Boulder & Guit-023 & Hydroxylapatite & Whit & Brown-beige & Main chamber \\
\hline Boulder & Guit-024 & Whitlockite & - & Brown-yellow & Bottom of the cave \\
\hline Asym. hollow & Guit-026 & Hydroxylapatite & - & Brown & Bottom of the cave \\
\hline Dark trickle & Guit-027 & Hydroxylapatite & - & Dark brown & Middle of the cave \\
\hline Dark trickle & Guit-028 & Hydroxylapatite & Whit & Dark brown & Middle of the cave \\
\hline Boulder & Guit-029a & Taranakite & Whit, Q, Gyp, Mcl & Dark brown & Bottom of the cave \\
\hline Boulder & Guit-029b & Whitlockite & $\mathrm{Hp}$ & Brown-yellow & Bottom of the cave \\
\hline $\begin{array}{l}\text { Aureole on } \\
\text { boulder }\end{array}$ & Guit-038 & Hydroxylapatite & - & Light beige & Main chamber \\
\hline Boulder & Guit-039 & Hydroxylapatite & $\mathrm{Q}$ & Black & Main chamber \\
\hline Crust & Guit-049 & Whitlockite & $\mathrm{Hp}$, Fap & Dark beige & Bottom of the cave \\
\hline Dark trickle & Guit-051 & Fluorapatite & Hp, Whit & Black & Bottom of the cave \\
\hline
\end{tabular}

\section{Prospecting pit $2(20 \mathrm{~cm}$ deep)}

Layer 1. Dry loose greyish material about $2 \mathrm{~cm}$ thick, containing organic debris. Minerals: newberyite and fluorapatite, brushite, gypsum, and quartz.

Layer 2. Unstratified dark brown organic level $(2 \mathrm{~cm}$ in thickness), in which the major mineral is brushite, mixed with ardealite and quartz. Irregular white nodules of gypsum are also present.
Layers 3 and 4. Alternating bedded brown and bright brown blankets of consolidated material $15 \mathrm{~cm}$ thick. Deprived of phosphates, the minerals identified are phyllosilicates and clays, typically associated with detrital inputs. Gypsum is also present.

Layer 5. One $\mathrm{cm}$ of sticky ochre mineral deposited over the underlying bedrock, formed by fluorapatite, accompanied by quartz and muscovite. 
Table 3. Mineral distribution and pH fields within the samples collected at guano heaps. Mus: muscovite; Ortho: orthoclase; Kaol: kaolinite; Cal: calcite; Dol: dolomite; It: illite-group mineral; Alb: albite; MC: Main Chamber; Bot: Bottom. Abbreviations as in Table 1 and 2.

\begin{tabular}{|c|c|c|c|c|c|c|c|}
\hline Unit & Site & $\begin{array}{c}\text { Layer (\#) / } \\
\text { Thickness } \\
\text { (cm) }\end{array}$ & pH & Sample & Main mineral & Associated minerals & Location \\
\hline \multirow{15}{*}{$\begin{array}{l}\text { HEAP } 1 \\
\text { (winter) }\end{array}$} & \multirow{4}{*}{$\begin{array}{l}\text { Prospecting } \\
\text { pit } 1\end{array}$} & (1) / 1 & 5.47 & Guit-030 \& 034 & Brushite-newberyite & $\mathrm{Q}$ & $\mathrm{MC}$ \\
\hline & & (2) / 3 & 4.92 & Guit-031 & Brushite & Q, Gyp & $\mathrm{MC}$ \\
\hline & & (3) / 6 & 4.66 & Guit-032 & Hydroxylapatite & $\mathrm{Br}, \mathrm{Q}$, Gyp & MC \\
\hline & & (4) / 1 & 5.31 & Guit-033 & Fluorapatite & Br, Q, Gyp & $\mathrm{MC}$ \\
\hline & \multirow{5}{*}{$\begin{array}{l}\text { Prospecting } \\
\text { pit } 2\end{array}$} & (1) / 2 & 6.66 & Guit-040 \& 041 & Newberyite & Fap, Q, Gyp, Br & $\mathrm{MC}$ \\
\hline & & (2) / 2 & 5.36 & Guit-042 & Brushite & Ar, Gyp, Q & $\mathrm{MC}$ \\
\hline & & (3) / 5 & 3.99 & Guit-062 & Quartz & Mus, Ortho, Kaol & $\mathrm{MC}$ \\
\hline & & (4) / 10 & 3.81 & Guit-063 & Gypsum & $\begin{array}{l}\text { Cal, Dol, Ortho, It, } \\
\text { Kaol }\end{array}$ & MC \\
\hline & & (5) / 1 & 4.84 & Guit-043 & Fluorapatite & Q, Mus & $\mathrm{MC}$ \\
\hline & \multirow{6}{*}{ Core } & (1) / 1 & 6.38 & Guit-053 & Gypsum & Q, Mus & $\mathrm{MC}$ \\
\hline & & (2) / 4 & 6.18 & Guit-054 & Gypsum & Q & $\mathrm{MC}$ \\
\hline & & (3) / 4 & 4.94 & Guit-060 & Taranakite & Q, Gyp, Alb & $\mathrm{MC}$ \\
\hline & & (4) / 3 & 4.07 & Guit-056 & Taranakite & Q, Mus & $\mathrm{MC}$ \\
\hline & & (5) / 5 & 4.57 & Guit-057 & Illite-group & Q, Ortho, Kao & $\mathrm{MC}$ \\
\hline & & (6) / 2 & 6.22 & Guit-058 & Quartz & Ortho, Alb, Kaol & $\mathrm{MC}$ \\
\hline \multirow{3}{*}{$\begin{array}{l}\text { HEAP } 3 \\
\text { (winter) }\end{array}$} & \multirow{3}{*}{$\begin{array}{l}\text { Guano } \\
\text { clearing }\end{array}$} & (1) / 2 & 4.75 & Guit-045 & Taranakite & Br, Q, Gyp & Bot \\
\hline & & (2) / 3 & 5.14 & Guit-046 & Whitlockite & $\mathrm{Hp}, \mathrm{Q}$ & Bot \\
\hline & & (3) / 4 & 6.46 & Guit-047 & Brushite & Gyp & Bot \\
\hline \multirow{2}{*}{$\begin{array}{l}\text { FEATURE } \\
\text { (winter) }\end{array}$} & Aureole & - & 5.28 & Guit-038 & Hydroxylapatite & - & MC \\
\hline & Black trickle & - & 5.30 & Guit-039 & Hydroxylapatite & $\mathrm{Q}$ & $\mathrm{MC}$ \\
\hline \multirow{9}{*}{$\begin{array}{l}\text { HEAP } 1 \\
\text { (spring- } \\
\text { summer) }\end{array}$} & \multirow{5}{*}{$\begin{array}{l}\text { Prospecting } \\
\text { pit } 3\end{array}$} & (1) / 2 & 7.75 & Guit-070 & Struvite & - & $\mathrm{MC}$ \\
\hline & & (2) / 5 & 6.20 & Guit-071 & Taranakite & $\mathrm{Q}, \mathrm{Alb}, \mathrm{Mus}$ & $\mathrm{MC}$ \\
\hline & & (3) / 7 & 3.54 & Guit-072 & Taranakite & Q, It & $\mathrm{MC}$ \\
\hline & & (4) / 14 & 3.60 & Guit-073 & Quartz & Mus, Kaol & $\mathrm{MC}$ \\
\hline & & (5) / 1 & 3.76 & Guit-074 & Hydroxylapatite & Dol, Cal, Q & $\mathrm{MC}$ \\
\hline & \multirow{4}{*}{ Surface } & - & & Guit-064 & Struvite & Q & $\mathrm{MC}$ \\
\hline & & - & & Guit-065 & Brushite & Q, Gyp, Mus & $\mathrm{MC}$ \\
\hline & & - & & Guit-067 & Struvite & Q, Gyp & $\mathrm{MC}$ \\
\hline & & - & & Guit-068 & Struvite & Q, Mus, Gyp & MC \\
\hline
\end{tabular}

Guano core (19 cm long) was sectioned and carefully examined at the laboratory of Universitat de les Illes Balears. Five stratigraphic layers were distinguished within the core extracted from the center of Heap 1. Layers 1,2 , and 3 would have suffered a certain compression when the PVC tube perforated the mound, thus their real thickness could be larger.

Layer 1. Dry conglomerate of grey flimsy material (1 $\mathrm{cm}$ thick), formed by organic debris covered by greenish crystals which in turn are smeared by tiny white crystals.

Layer 2. Coarsely bedded, dark brownish material (4 $\mathrm{cm}$ thick), composed of intertwined insect fragments and organic debris. In the upper two units, gypsum is the principal mineral phase, occurring with quartz and muscovite. No trace of phosphates.

Layer 3. More compacted dark brownish accumulation of organic debris ( $4 \mathrm{~cm}$ thick), which its lower section filled with abundant masses of white minerals.

Layer 4. Bedded deep brown clayey material $3 \mathrm{~cm}$ thick, containing beige irregular nodules. In these intermediate units (layers 3 and 4), the dominant mineral is taranakite, associated with quartz, albite, and muscovite; gypsum has also been reported.

Layer 5. Fine gritty-clayey bright brown material (5 $\mathrm{cm}$ in thickness). No trace of phosphates, the minerals identified include illite-group minerals, quartz, orthoclase, and kaolinite.

Layer 6 . Two $\mathrm{cm}$ thick deposit with similar visual appearance to layer 5 , but containing quartz, orthoclase, albite, and kaolinite.

Additionally, during the winter campaign a lateral guano boring was also made at Heap 3 in order to reveal its inner composition:

Layer 1 . Black highly pasty deposit $(2 \mathrm{~cm}$ thick). The predominant mineral is taranakite, mixed with brushite, quartz, and gypsum.

Layer 2. Ochre clay material, $3 \mathrm{~cm}$ thick, whose major mineral phase is constituted by whitlockite, associated with hydroxylapatite and quartz.

Layer 3. White mass $4 \mathrm{~cm}$ thick, with abundant gypsum and brushite.

The second campaign happened during the month of June, when the breeding colony of bats was in the 
chamber. To minimize any disturbance to the bat colony, a single prospecting pit (\#3) was excavated at Heap 1, collecting several samples from the surface as well.

Prospecting pit 3 (30 cm deep), located in an area with fresh guano and abundant bat droppings.

Layer 1. Loose and sticky dark brown organic level formed by organic debris $(3 \mathrm{~cm}$ thick). It should be noted the presence of abundant white masses, candyfloss shaped, covering the surface of most of the guano heap, probably fungi. The dominant and only mineral is struvite.

Layers 2 and 3. More compacted light brownish to yellowish material totaling $12 \mathrm{~cm}$ in thickness, whose upper part still contains some organic debris, while the rest of the layer shows abundant irregular whitish nodules. The main phase is taranakite, associated with quartz, muscovite, and illite-group minerals.

Layer 4. Massive bedded brown clayey material, $14 \mathrm{~cm}$ in thickness, composed of quartz, muscovite, and kaolinite.

Layer 5. Gritty yellowish crust $(1 \mathrm{~cm})$ developed at the top of an embedded fragment of limestone; it is mainly composed of hydroxylapatite, accompanied with dolomite, calcite, and quartz.

\section{DISCUSSION}

\section{Microclimatic constraints}

The upper passages of Cova de sa Guitarreta (until reaching its main chamber) could be considered as a "cold trap cave" (Racoviță, 1975; Cigna, 2004), where the seasonal variation of outside air temperatures causes that in the winter or cooler months, the cold, drier, and denser outside air flows downward blowing out the warmer, less dense cave air, remaining in equilibrium or with a limited circulation for the rest of the year. The configuration and topography of the cave enhances this pattern (Figs. 1 and 10). Its entrance section profile funnels the sinking of cool air during the winter months, creating an inward draught of drier air, which eventually provokes variations in the microclimatic conditions of the cave.

Towards the end of the winter (March), temperature, relative humidity $(\mathrm{RH})$ and $\mathrm{CO}_{2}$ concentration were documented. Whilst the ambient outside temperature was $12^{\circ} \mathrm{C}, \mathrm{RH} 65 \%$ and $\mathrm{CO}_{2}$ concentration was 420 ppm, these parameters at Heap 1 , were $22.4^{\circ} \mathrm{C}, \mathrm{RH}$ $96 \%, \mathrm{CO}_{2} 525$ ppm; at Heap 2, were $22.8^{\circ} \mathrm{C}$, RH 99\%, $\mathrm{CO}_{2} 527 \mathrm{ppm}$; and at Heap 3, 24.1 ${ }^{\circ} \mathrm{C}, \mathrm{RH} 99 \%, \mathrm{CO}_{2}$ $741 \mathrm{ppm}$. The incoming air from outside has a subtle direct effect lowering the $\mathrm{RH}$ at the main chamber, whereas it is close to saturation at the inner and deepest sections of the cave. As we approach to the thermal water pool, air temperature significantly increases with depth. $\mathrm{CO}_{2}$ levels raises but not as much as it could be expected, showing a certain air exchange with the exterior. Conversely, warmer or hotter months provide more stable conditions of humidity and temperature, with a drastic reduction of penetrating airflows. Moreover, the existence of a geothermal gradient, with phreatic waters that reach $27.7^{\circ} \mathrm{C}$, significantly contributes to the cave warming and dampening throughout the whole year. The cave atmosphere presents a particular environment due to the geothermal anomalies that affect the cave.

The scarcity and small dimensions of the bell holes could be associated with the phreatic waters' anomalous high temperature. Lundberg and McFarlane (2008) suggest that such features develop through bat-boosted condensation corrosion process concentrated on sites chosen by bats. They conclude that, because of bats metabolic activity, bell holes with bats show a warmer temperature producing also significant amounts of water and $\mathrm{CO}_{2}$, inducing condensation of aggressive water on to the cooler limestone walls and hence dissolution. During bat foraging periods bell holes temperature must return to normal, mainly by heat transfer through the cold bedrock, in order to allow subsequent condensation processes.

In Cova de sa Guitarreta, the continuous warm vapor produced at the surface of the phreatic water table ascends along the fissures into the bell-shaped main chamber, causing the existence of a warm and humid air layer in close contact with the roof. This layer of air has a stable temperature of $23-25.7^{\circ} \mathrm{C}$ during the breeding season (Fig. 10), well above the mean annual exterior temperature $\left(18^{\circ} \mathrm{C}\right)$ of the region (López, 2007). This peculiarity along with the bell-shaped configuration of the chamber, partially prevents the bedrock surface from cooling while bats are away during the night. Therefore, limiting the condensation process to the periods when cool outside air descends into the cave causing convective cells, situation that is less frequent between April and August. Furthermore, we have measured the temperature of the main dense bat cluster present in the ceiling of the chamber, yielding a maximum of $36^{\circ} \mathrm{C}$ (Fig. 10). Mean annual highest and lowest temperatures in the region during the breeding period (months in yellow in Supplementary Table 1) are rather mild (Guijarro, 1986).

Considering the mean temperature in the chamber, about $22-23^{\circ} \mathrm{C}$ (Fig. 10), we can deduct that penetration of cool air happens during periods when the outside temperatures are lower than the cave temperature, commonly at nighttime during bats breeding season. In addition, air movements caused by bat flight while entering or exiting, or during roosting periods of activity, could also help to disperse and mix the two air masses allowing some surface cooling (Lundberg \& McFarlane, 2015). In fact, we have observed that when bats start their flight to exit the cave for foraging, they take off by falling before becoming airborne from their location, flying around and descending in counterclockwise circles until they reach the optimal level to escape the chamber. This movement of hundreds of individuals causes a vortex of air that is clearly felt and could facilitate the dissipation of the warmer layer of air.

\section{Guano mounds characteristics}

Heap 1 is located at the eastern sector of the main chamber, which is floored by an alluvial fan of allochthonous sediments, boulders of different sizes, mud silts and clays, that spreads out from the base of the entrance pit. 


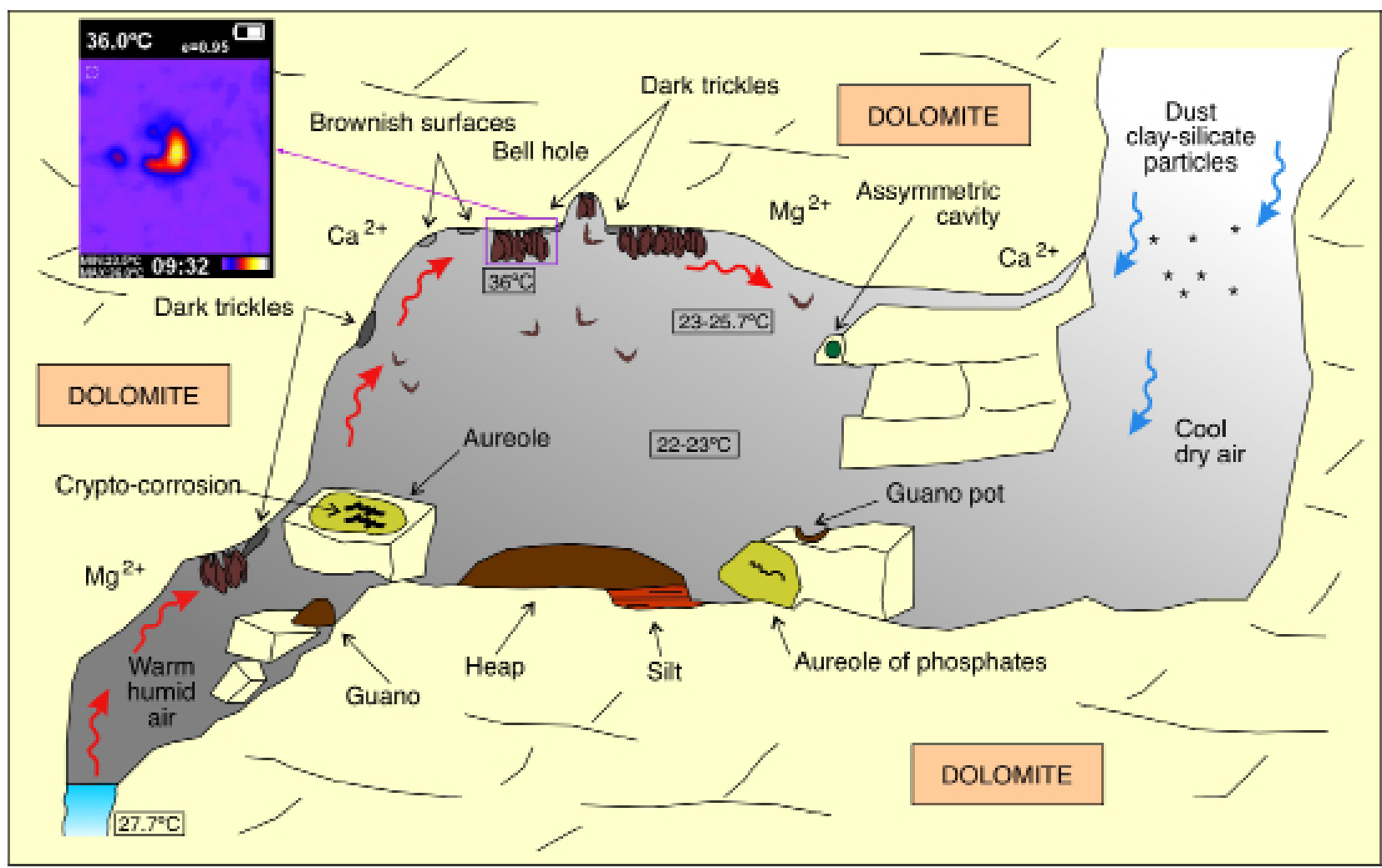

Fig. 10. Idealized sketch showing the features related to guano deposits and bat excreta present in the cave. Left upper corner inset: thermal imaging of the main bat cluster situated in the chamber exhibiting a temperature of $36^{\circ} \mathrm{C}$ at its center, while the surrounding area reaches $23.5^{\circ} \mathrm{C}$.

Prospecting pits and core extraction have allowed to observe the whole sequence of materials that form Heap 1 and shed some light on its structure and mineral assemblage (Table 3). The different layers clearly represent an irregular guano deposit influenced by the deposition of detrital sediments, rock boulders and clay materials, brought into the cave by seasonal flashfloods after strong rainfalls. The upper section corresponds to a fresh or recent guano layer that undergoes a first stage of guano decomposition, causing the precipitation of the omnipresent gypsum and precursors phosphates like struvite, newberyite, and brushite, containing quartz of detrital origin. In the intermediate unit, organic matter degradation increases and percolation of phosphatic acid solutions react with the clayey deposits, releasing $\mathrm{Al}$ and $\mathrm{K}$ and forming taranakite, which is accompanied by abundant phyllosilicates. The lower section, in contact with the underlying limestone bedrock, shows alteration crusts constituted by hydroxylapatite and fluorapatite, along with phyllosilicates. Scattered limestone boulders intermingled within the intermediate and deepest section, also display hydroxylapatite coatings.

\section{Guano-related minerals}

\section{Phosphates}

Most of the following minerals are associated with quartz and gypsum (Table 1 and 3).

Ardealite, displays a grayish nodular aggregate that develop on a boulder wall, covering an important surface. This cave mineral is associated with brushite, which points to $\mathrm{pH}$ values situated above 5.5 and below 8 (Ferreira et al., 2003; Arifuzzaman \& Rohani, 2004; Onac et al., 2005). This assemblage is totally new in the cave since the previously published paper by Onac et al., 2005, identified ardealite without being associated with other minerals, which would indicate a totally different acid environment with a $\mathrm{pH}$ below 5.5 . This mineral precipitation is caused by the reaction of sulfuric and phosphoric acids with calcite, at the early stages of guano decomposition (Hill \& Forti, 1997; Puşcass et al., 2014; Audra et al., 2019).

Brushite, has been identified as traces intermingled with ardealite on a boulder wall. Brushite is also present at all guano heaps, mainly at the surface or in the layer immediately below as an earthy or pasty material. It is commonly found associated with newberyite, and on rare occasions with taranakite, hydroxylapatite, and fluorapatite. Only at Heap 3 this mineral is located at the bottom of the guano pile, probably due to its limited thickness.

Traces of collinsite were discovered within a black earthy mixture of phosphates containing hydroxylapatite, on the floor of a pile of a boulders choke located to the west of the chamber, about $4 \mathrm{~m}$ above its floor. The precipitation of this mineral takes place in a rather moistened environment, when $\mathrm{Mg}$ rich solutions pass through a guano layer, reacting with the surface of a limestone block (Onac et al., 2009). Interestingly, current conditions on this site are far from being damp, showing a quite dry powdery material.

Hydroxylapatite is a ubiquitous and abundant mineral in the cave, being the most thermodynamically stable phosphate under ordinary cave conditions (Onac \& Veres, 2003; Onac et al., 2005). It has been identified associated with whitlockite in eight samples, with brushite in one sample, and with collinsite in another sample. Hydroxylapatite exhibits a wide range of colors and textures, from brownish to black 
thin crusts on ceiling trickles, grayish to ochre layer or isolated aureoles on rock boulders that can show crypto-corrosion features. It also exhibits protruding thin dark brown crusts present on weathered walls and light ochre layers under guano accumulations. It forms brown to light brown coatings overlying guano pots and occurs at the lower layers of the three studied guano piles.

Many fallen rocks are covered by a dark-yellowish aureole composed mainly of this phosphate, which would indicate that in the past, the cave harbored larger and more abundant bad colonies. The aureoles situated at the deepest section, display pastier texture of the mineral crust as a consequence of the prevailing moister conditions, whereas the more ventilated and drier chamber also exhibits grey powdery deposits composed of hydroxylapatite.

When in the hydroxylapatite molecule the hydroxyl ion is replaced by fluorine, fluorapatite forms. This phosphate has been found at two different locations within Heap 1, firstly in one sample from an ochre alteration crust at the bottom of prospecting pit 1 , associated with brushite. Secondly, at the upper layer of prospecting pit 2 intermingled with newberyite, and in the lower layer as the main mineral phase. Finally, it is intermixed with hydroxylapatite and whitlockite in a dark trickle crust at Heap 2.

The host-rock is composed mainly of calcarenites belonging to the Reef Complex that is Upper TortonianLower Messinian in age (Pomar et al., 1996), which in this area are almost pure dolomite and calcite, without traces of fluorine. The main plausible source of this element could be the bat urine and to a lesser extent bat bones accumulation. Although the latter one is likely during periods when the cave is occupied by maternity colonies, currently no bone remains have been found. In addition, the dark trickles located at Heap 2, clearly point out to be caused by urine jets while bats hang to the overhanging wall. On the other hand, the occurrence of fluorapatite at the bottom of Heap 1 would reveal the removal of fluorine by percolating water or moisture passing through the guano pile, reacting with the carbonate rock that lies underneath.

Newberyite. Most samples that include this phosphate are mixtures of two or three minerals that exhibit a crumbly texture and were collected when the cave was totally free of bats. It develops on the surface or immediately below the decomposed main guano accumulation of Heap 1, at a $\mathrm{pH}$ spanning from 5.47 to 6.66 , associated with brushite, gypsum, and quartz. It is known that newberyite is more likely to occur in caves with warm and dry microclimatic conditions (Hill \& Forti, 1997). This mineral was first found during the winter and early spring when inflow of outside air occurs. We hypothesize that the drier environment existing between late autumn and middle spring, caused by entering cold and drier airflows and the lack of harboring bat colonies to release their byproducts, would result in the transformation of metastable struvite into a more stable newberyite.

Struvite. All samples containing this hexahydrate phosphate were collected from the surface of an active guano deposit (Heap 1), when the reproductive bat colony was occupying the cave. The mineral is present between a friable mass, intermixed with gypsum and quartz, and with the presence of abundant fungi that develop on the guano surface, suggesting the possible role of microbial activity in the precipitation of this mineral.

Taranakite was discovered at the surface of an altered guano deposit, Heap 3, mixed with brushite, forming an ochre-colored dark brown thin layer that overlies another mineral coating formed by hydroxylapatite and whitlockite, which in turn covers the bedrock. It has also been clearly identified at Heap 1 (core), as an intermediate brown pasty layer accompanied by different silicates, albite, muscovite, kaolinite, orthoclase and illite-group minerals. The precipitation of this phosphate occurs when acidic guano leachates react with allogenic sediments, mainly clays, causing the hydrolysis of weak phyllosilicates, which releases $\mathrm{Al}^{3+}$ and $\mathrm{K}^{+}$. These cations would combine with phosphoric acid to form taranakite.

Whitlockite is an abundant phosphate in the cave and has been identified predominantly occurring as lightbrown to black earthy masses on fallen rocks, or brown to dark-brown crusts on wall and ceiling trickles. In most of the occurrences, it is associated with hydroxylapatite. It has also been found at guano clearing of Heap 3, occurring at a measured $\mathrm{pH}$ value of 5.14 along with hydroxylapatite. Whitlockite forms when guano decomposition leachates react with dolomitic carbonate host rock. The precipitation of whitlockite consumes most of the available $\mathrm{Mg}^{2+}$, causing an increase of the $\mathrm{Ca} / \mathrm{Mg}$ ratio that favors the formation of hydroxylapatite (Puscaş et al., 2014; Audra et al., 2019). Furthermore, whitlockite is stable within a narrow acidic $\mathrm{pH}$ field, around 5, whereas hydroxylapatite can exist over a wider $\mathrm{pH}$ range, from 4.2 up to neutral $\mathrm{pH}$ (Hae et al., 2014). Therefore, the abundance of one mineral phase over the other, could indicate more favorable $\mathrm{pH}$ environment (Fig. 11).

\begin{tabular}{|c|c|c|c|c|c|c|}
\hline $\mathrm{pH}$ & 3 & 4 & 5 & 6 & 7 & 8 \\
\hline Brushite & & & & & & \\
\hline Newberyite & & & & & & \\
\hline Hydroxylapatite & & & & & & \\
\hline Fluorapatite & & & & & & \\
\hline Taranakite & & & & & & \\
\hline Whitlockite & & & & & & \\
\hline Struvite & & & & & $\square$ & \\
\hline Ardealite & & & $\square$ & & & \\
\hline Collinsite & & & (?) & & & \\
\hline
\end{tabular}

Fig. 11. Approximate $\mathrm{pH}$ range of stability of described phosphate minerals in Cova de sa Guitarreta.

\section{The dichotomy between struvite and newberyite}

Both minerals have been clearly identified at Heap 1 , but not together or in the same period of the year. Struvite was identified on the surface of Heap 1, at $\mathrm{pH}$ 7.75 only during the period when the cave is occupied by bats and the microclimate conditions are more stable and wet. It is mixed with gypsum and quartz in a crumbly mass, in which no other phosphate has been identified. The precipitation of this slightly soluble mineral is controlled by $\mathrm{pH}$, availability of $\mathrm{Mg}^{2+}$ 
and the content of ammonia that should be higher than that of magnesium (Babić-Ivančić et al., 2006; Hao et al., 2008). The $\mathrm{pH}$ range for the formation of this phosphate is located between 7.0 and 9.0, depending on the $\mathrm{Ca}^{2+}$ content (Hao et al., 2008). The $\mathrm{Mg}^{2+}$ ions required for the formation of struvite are probably supplied by the fall of detached particles of dolomite from ceiling and wall, due to biomechanical erosion produced by bats when hanging to the rock or when they move across its surface using hind feet and thumbs, or to a lesser extent by dripping of solutes originated from condensation processes. Ammonium, $\mathrm{NH}_{4}^{+}$, comes from the decomposition of the abundant bat urine and bat droppings generated by the main colony above. Struvite is a low stability phosphate which easily decomposes by water and ammonia $\left(\mathrm{NH}_{3}\right)$ loss, triggering the formation of newberyite (Cohen, 1966; Snow et al., 2014); this conversion is followed by a pH drop (Babić-Ivančić et al., 2006).

\section{Other minerals}

Gypsum. This already known mineral in the cave exhibits a thin white crust covering some boulders surfaces in the northern part of the chamber (Fig. 12), near the access to the subvertical pit that leads to the outside. In addition, it has been identified throughout different layers that form the guano heaps, exhibiting small aggregates interspersed among other minerals and organic debris.

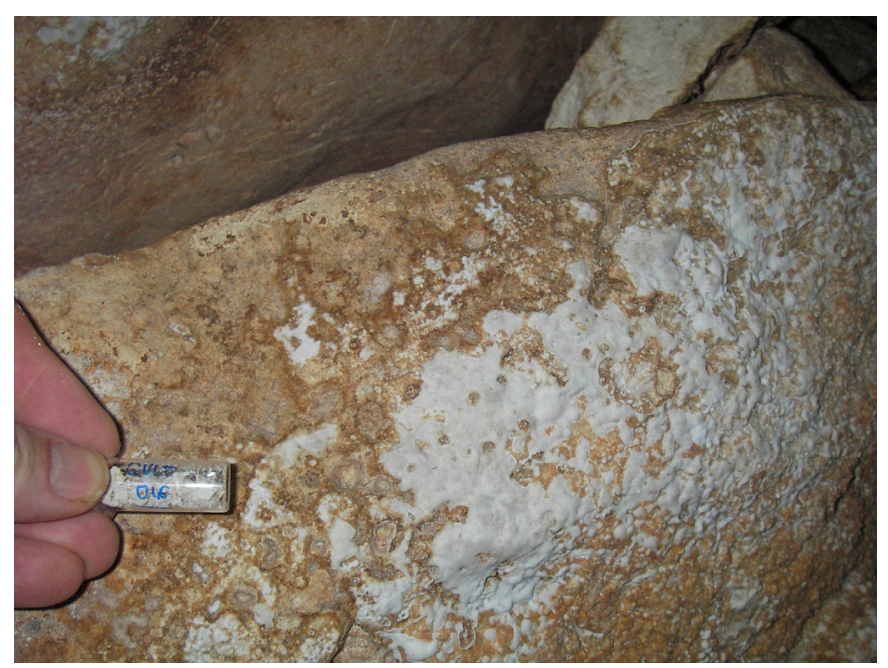

Fig. 12. Gypsum blisters covering a fallen boulder located in a wellventilated area that is affected by outside air flows.

Gypsum is present in a section of the chamber whose wall is formed by a pile of rocks, not far from Heap 1, which is affected by inward drier outside air, causing an evaporative process where this mineral can precipitate, forming white crusts or blisters. On this site, huntite has also been identified, supporting an evaporitic environment, as predicted by Hill and Forti (1997). This occurrence could indicate that leachates containing dissolved sulfate, from the guano pile, may have migrated by capillary flow to the more ventilated area, where evaporation would have allowed gypsum crystallization. Gypsum has also been identified at all guano mounds, being more abundant at Heap 1, where exists at all layers including the upper surface. This rather soluble mineral can remain in dry or relatively dry conditions, therefore, preferably at a certain distance from dripping point areas. The chemical mechanism involved in the precipitation of this mineral would be the reaction between the sulfates-rich leached solution derived from bat guano and the underlying carbonate bedrock (Onac et al., 2005).

Quartz. Although not a cave mineral, quartz is present in most of the analyzed samples. Since the host-rock is mainly dolomite without any traces of quartz, its origin from direct interaction between the rock and guano decaying lixiviates is excluded. The origin of quartz could be ascribed to two different scenarios, both related to Saharan dust that periodically occurs at these latitudes (Supplementary Fig. 1). When fine quartz particles are found on the surface or slightly below guano mounds, we speculate that the wind-blown Saharan dust, would have been transported into the cave by strong air flow and deposited on the surface of guano mounds. Instead, if quartz is intermingled with other minerals in middle or bottom layers within the guano mounds, its origin would be detrital materials swept into the cave by periodical flash flood. This process would also be the source for the deposition of phyllosilicates and feldspar minerals, such as muscovite, orthoclase, and microcline, albite, and kaolinite (Supplementary Fig. 1).

\section{Acidity profiles, $\mathrm{pH}$, and guano-related mineral genesis}

Although the thickness of the guano deposits in Cova de sa Guitarreta is quite modest in comparison with other caves (Onac et al., 2007; Giurgiu \& Tămaş, 2013; Puşcaş et al., 2014; Audra et al., 2019, 2021; Dandurand et al., 2019), the acidity profile and the mineral distribution within them clearly represents the physicochemical processes caused by guano decay in a warm and humid environment.

The upper loose layer of Heap 1 exhibits a marked physicochemical dynamism in comparison with the rest of the guano levels. Alternating periods of bat droppings accumulation and a more stable microclimate, with longer intervals when the cave microclimate is highly influenced by the inflow of drier and cooler outside air, along with the absence of bats, cause a change in the moist conditions and $\mathrm{pH}$ level, thus, in the precipitation of minerals. The upper layer of Heap 1 shows a $\mathrm{pH}$ higher than neutral, 7.75 when fresh droppings happen (prospecting pit 3), with struvite the more significant phase. The $\mathrm{pH}$ and moisture progressively decrease, reaching between 5.47 and 6.38 as bats leave the cave after the reproduction period (prospecting pits 1 and 2) (Table 3) provoking the precipitation of newberyite. This could be explained due to the presence of abundant bat urine which is enriched in urea that upon microbial decomposition transforms into ammonia (McFarlane et al., 1995; James, 2013; Dandurand et al., 2019; Barriquand et al., 2021) causing a more alkaline environment. Urea is also present in fresh guano which can decay to $\mathrm{NH}_{3}$, under moist environment by the enzyme urease (Snow et al., 2014). In June, when the cave was occupied by bats, the central area of guano Heap 1 emitted a quite clear 
odor of ammonia. Conversely, when bat droppings cease during winter, the fresh decaying guano undergoes a chain of chemical reactions that release acidic solutions that lowers the $\mathrm{pH}$. Such changes in the acidity at the surface of the guano mound lead to different environmental conditions that control the stability of minerals.

As we get deeper into the guano sequence, its organic decay steadily generates acidic leachates, causing the $\mathrm{pH}$ to drop until reaching an acidic environment at 3.54 (prospecting pit 3). The bottom section of prospecting pits 1 and 2 shows a feeble increase to 5.31 and 4.84 respectively, that could be related to neutralization processes between acidic solutions and the limestone host rock (Audra et al., 2019). Prospecting pit 3 shows a different stratification since we could not reach the bedrock layer, but in any case, the $\mathrm{pH}$ starts to slightly rise between 25 and $30 \mathrm{~cm}$ deep. The limited thickness of Heap 3 could explain the acidity profile, which is moderately low ( $\mathrm{pH} 4.75)$ at surface and increases to near neutral, 6.46, at the bottom, next to the contact between the guano deposit and the limestone pavement.

The anomalous stability of hydroxylapatite under acidic conditions with $\mathrm{pH}$ spanning from 4.66 up to 5.30 could be partially explained by the fact that this phosphate is accompanied by other acidic related species, like brushite, both precipitating from the same solution as its $\mathrm{pH}$ changes. In this case, the proportion between one phosphate over the other, would indicate a local appropriate $\mathrm{pH}$ value.

The aureoles and black trickles, formed by hydroxylapatite, testify old locations where bats congregated, but are inactive at present; they show a fluctuation of $\mathrm{pH}$ values between 5.28 and 5.30, which indicates that acidity conditions persist over long periods of time.

Brushite, ardealite, and taranakite are stable under damp and acidic conditions, $\mathrm{pH}<6$ (Hill \& Forti 1997); in Cova de sa Guitarreta, the $\mathrm{pH}$ values for the first mineral, are between 4.66 and 6.66, for ardealite 5.36, whereas taranakite precipitates at a more acidic environment ranging from 3.54 to 6.20 . On one location, brushite occurs at pH 6.66 (above its common value), which may indicate a $\mathrm{Mg} / \mathrm{Ca}$ ratio about 4 (Giurgiu \& Tămaş, 2013); the identification of newberyite in this sample, strongly supports this hypothesis.

\section{CONCLUSIONS}

Cova de sa Guitarreta appears as a remarkable site for bat-related features and guano- associated cave minerals. Among the nine identified phosphates, newberyite, struvite, and whitlockite are described for the first time in caves in Mallorca.

The general microclimate of the cave is clearly influenced by the existence of a thermal phreatic water table pool $\left(27.7^{\circ} \mathrm{C}\right)$, which contributes to cave warming and moistening throughout the year. Therefore, the condensation-corrosion phenomena, enhanced by the presence of bats, and the specific morphologies they create, are all influenced by this thermal factor.
The post-speleogenetic evolution of the cave is mainly controlled by the following processes induced by the presence of bats: 1) Biomechanical erosion represented by bat scratches: bat claws and thumbs marks; 2) Weathering of limestone surfaces, floors, walls, and fallen rocks, related to aggressive leachates derived from guano and bat excreta decomposition, produce crypto-corrosion, asymmetrical cavities, guano pots, weathered walls, dark trickles, and brown surfaces; 3) Restricted batenhanced condensation-corrosion processes that generates bell-holes.

The singular occurrence and succession of struvite and newberyite reported from Cova de sa Guitarreta, demonstrates for the first time, that cave microclimate and the presence of bats influence the seasonal transformation of the former phosphate into the latter phosphate mineral during the colder seasons.

The cave is not continuously occupied by bats. The effect of the high temperature environment would have been a deterrent for bats to use the cave as a hibernate shelter. On the contrary, it would have facilitated the occupation of the cave by pregnant females and procreation during short periods of time along the year.

The extensive brown-yellowish phosphate crusts and aureoles, composed mainly of hydroxylapatite, suggest that in the past, the cave was inhabited by a larger bat population. These phosphatic deposits line fallen blocks located fundamentally, at the inner part of the cave and certain areas of the main chamber.

Caves with seasonal cyclical occupation of bat colonies could provide a new field for studying mineral assemblages that occur mainly on the surface of guano mounds or slightly below them. Monthly sampling would allow better understanding of the decomposition sequences of, among others, the metastable phosphates containing ammonia. Future research would have to include in situ analyses with portable analytical devices as well as year-round monitoring campaigns with data-loggers.

\section{ACKNOWLEDGEMENTS}

The cave is managed and under the protection of the Regional Environment Authorities. We thank the Direcció General d'Espais Naturals i Biodiversitat del Govern de les Illes Balears for granting permission to perform research in the cave. We are indebted to Ferran Hierro and Joan Cifre of Serveis CientificoTècnics de la UIB, for their support in analyzing the mineral samples. José Bermejo and his survey team are thanked for allowing us to use the cave map and the information provided about the cave. We acknowledge the Agencia Estatal de Investigación (AEI), for its support to the project <PID2020112720GB-I00/AEI/10.13039/501100011033>. We appreciate the suggestions made by the reviewers, Paolo Forti and Philippe Audra, which helped to improve the original manuscript. Bogdan P. Onac is gratefully acknowledged for improving the English style and his support and detailed constructive comments. 
Authorship statement: AMe designed and directed the study, participated in all sampling and field surveying campaigns, and wrote the paper with input from all authors. AMu participated in the sampling and field survey campaign. JJF performed mineral analysis. JG started the morphological and genetic observations in the cave in the last decades. All authors discussed the results, contributed, and revised the final manuscript.

\section{REFERENCES}

Alcover, J.A., Muntaner, J., 1986. Els quiròpters de les Balears i Pitiüses: una revisió. Endins, 12, 51-63.

Arifuzzaman, S.M., Rohani, S., 2004. Experimental study of brushite precipitation. Journal of Crystal Growth, 267, 624-634.

https://doi.org/10.1016/j.jcrysgro.2004.04.024

Audra, P., Barriquand, L., Bigot, J.Y., Caihol, D., Caillaud, H., Vanara, N., Nobécourt, J.C. Madonia, G., Vattano, M., Renda, M., 2016. L'impact méconnu des chauvessouris et du guano dans l'évolution morphologique tardive des cavernes. Karstologia, 68, 1-20.

Audra, P., De Waele, J., Bentaleb, I., Chroňáková, A., Krištůfek, V., et al, 2019. Guano-related phosphaterich minerals in European caves. International Journal of Speleology, 48(1), 75-105.

https://doi.org/10.5038/1827-806X.48.1.2252

Audra, P., Heresanu, V., Barriquand, L., El Kadiri Boutchich, M., Jaillet, S., Pons-Branchu, E., Bosák, P., Cheng, H., Edwards, R.L., Renda, M., 2021. Bat guano minerals and mineralization processes in Chameau Cave, Eastern Morocco. International Journal of Speleology, 50(1), 91-109.

https://doi.org/10.5038/1827-806X.50.1.2374

Babić-Ivančić, V., Kontrec, J., Brečević, L., Kralj, D., 2006. Kinetics of struvite to newberyite transformation in the precipitation system $\mathrm{MgCl}_{2}-\mathrm{NH}_{4} \mathrm{H}_{2} \mathrm{PO}_{4}-\mathrm{NaOH}-$ $\mathrm{H}_{2} \mathrm{O}$. Water Research, 40, 3447-3455.

https://doi.org/10.1016/j.watres.2006.07.026

Balcells, E., 1968. Interesantes datos faunísticos y biológicos de la cueva "Sa Guitarreta" de Llucmajor. Boletín de la Sociedad de Historia Natural de Baleares, 14, 3-4.

Barriquand, L., Bigot, J.Y., Audra, P., Cailhol, D., Gauchon, C., Heresanu, V., Jaillet, S., Vanara, N., 2021. Cave and bats: Morphological impacts and archaeological implications. The Azé Prehistoric Cave (Saône-et-Loire, France). Geomorphology, 388, 107785.

https://doi.org/10.1016/j.geomorph.2021.107785

Bermejo, J., Pardo, J.V., Mulet, G., Mateu, T., 2021. Cova de sa Guitarreta (Llucmajor, Mallorca). Gota a Gota, 25, 20-27.

Cigna, A.A., 2004. Climate in caves. Encyclopedia of caves and karst science. Fitzroy Dearborn, p 467-475.

Cohen, L.H., 1966. Magnesium phosphate mineral replacement at Mono lake, California. The American Mineralogist, 51, 1755-1765.

Dandurand, G., Duranthon, F., Jarry, M., Stratford, D.J., Bruxelles, L., 2019. Biogenic corrosion caused by bats in Drotsky's Cave (the Gcwihaba Hills, NW Botswana). Geomorpholgy, 327, 284-296.

https://doi.org/10.1016/j.geomorph.2018.10.027

Dittmar, K., Dick, C.W, Patterson, B.D.,Whiting, M.F., Gruwell, M.E., 2009. Pupal deposition and ecology of bat flies (Diptera: Streblidae): Trichobius sp. (Caecus group) in a Mexican cave habitat. The Journal of
Parasitology, 95(2), 308-314.

https://doi.org/10.1645/GE-1664.1

Ferreira, A., Oliveira, C., Rocha, F., 2003. The different phases in the precipitation of dicalcium phosphate dihydrate. Journal of Crystal Growth, 252, 599-611. https://doi.org/10.1016/S0022-0248(03)00899-6

Ginés, A., 1982 Inventario de las especies cavernícolas de las Islas Baleares. Endins, 9, 57-75.

Ginés, J., Ginés, A., 2009. Proposta d'una nova classificació morfogenètica de les cavitats càrstiques de l'illa de Mallorca. Endins, 33, 5-18.

Ginés, J., Fornós, J.J., Gràcia, F., Merino, A., Onac, B.P., Ginés, A., 2017. Hypogene imprints in coastal karst caves of Mallorca Island (Western Mediterranean): morphological features and speleogenetic approach. In: Klimchouk, A., Palmer, A.N., de Waele, J., Auler, A.S., Audra, P. (eds.) Hypogene karst regions and caves of the world. Springer International Publishing, Cham. p. 99112. https://doi.org/10.1007/978-3-319-53348-3 5

Giurgiu, A., Tămaş, T., 2013. Mineralogical data on bat guano deposits from three Romanian caves. Studia UBB Geologia, 58(2), 13-18.

https://doi.org/10.5038/1937-8602.58.2.2

Guijarro, J.A., 1986. Contribución a la bioclimatología de Baleares. Unpublished PhD Thesis. Universitat de les Illes Baleares.

Hae, L. J., Kyoungsuk, J., Jaehun, L., Younghye, K., Seung, H. N., Kug, S. H., Ki Tae, N., 2014. Revisiting whitlockite, the second most abundant biomineral in bone: nanocrystal synthesis in physiologically relevant conditions and biocompatibility evaluation. ACS Nano, 8(1), 634-641. https://doi.org/10.1021/nn405246h

Hao, X.D., Wang, C.C., Lan, L., Van Loosdrecht, M.C.M., 2008. Struvite formation, analytical methods and effects of $\mathrm{pH}$ and $\mathrm{Ca}^{2+}$. Water Science \& Technology, 58.8, 1687-1692. https://doi.org/10.2166/wst.2008.557

Hill, C., Forti, P., 1997. Cave minerals of the world (2nd ed.). National Speleological Society, Huntsville, Alabama, $464 \mathrm{p}$.

James, J.M., 2013. Atmospheric processes in caves. In: Shroder, J. (Editor in Chief), Frumkin, A. (Ed.), Treatise on Geomorphology. Academic Press, San Diego, vol. 6, Karst Geomorphology, p. 304-318.

https://doi.org/10.1016/B978-0-12-374739-6.00118-4

López, J.M., 2007. Las manifestaciones hidrotermales del sur de Llucmajor, Mallorca. Memòria d'Investigació, Departament de Ciències de la Terra, Universitat de les Illes Balears. Unpublished. 132 p.

López, J.M., Mateos, R.M., 2006. Control estructural de las anomalías geotérmicas y la intrusión marina en la plataforma de Llucmajor y la cubeta de Campos (Mallorca). Instituto Geológico y Minero de España, Serie Hidrogeología y Aguas Subterráneas, 17, 607-613.

Lundberg, J., McFarlane, D.A., 2008. Bats and bell holes: The microclimatic impact of bat roosting, using a case study from Runaway Bay Caves, Jamaica. Geomorphology, 106, 78-85.

https://doi.org/10.1016/j.geomorph.2008.09.022

Lundberg, J., McFarlane, D.A., 2015. Microclimate and niche constructionism in tropical bat caves: A case study from Mount Elgon, Kenya. In: Feinberg, J., Gao, Y., Alexander, E.C. Jr. (Eds.) Caves and karst across time. Geological Society of America Special Paper, 516.

McFarlane, D., Keeler, R.-C., Mizutani, H., 1995. Ammonia volatilization in a Mexican bat cave ecosystem. Biogeochemistry, 30, 1-8.

https://doi.org/10.1007/BF02181037

McFarlane, D.A., Lundberg, J., 2018. New records of guano-associated minerals from caves in northwestern 
Borneo. International Journal of Speleology, 47(2), 119126. https://doi.org/10.5038/1827-806X.47.2.2169

Merino, A., Fornós, J.J., Mulet, A., Ginés, J., 2019. Morphological and mineralogical evidence for ancient bat presence in Cova des pas de Vallgornera (Llucmajor, Mallorca, Western Mediterranean. International Journal of Speleology, 48(2), 115-131. https://doi.org/10.5038/1827-806X.48.2.2247

Merino, A., Ginés, J., Fornós, J.J., 2011. Evidències morfològiques de processos hipogènics a cavitats de Mallorca. Endins, 35, 165-182.

Onac, B.P., Breban, R., Kearns, J., Tămaş, T. 2002 Unsual minerals related to phosphates deposits in Cioclovina Cave, Şureanu Mts. (Romania). Theoretical and Applied Karstology 15, 27-34.

Onac, B.P., Veres, D.S., 2003. Sequence of secondary phosphates deposition in a karstenvironment: evidence from Magurici Cave (Romania). European Journal of Mineralogy, 15(4), 741-745. https://doi.org/10.1127/0935-1221/2003/0015-0741

Onac, B.P., Fornós, J.J., Ginés, A., Ginés, J., 2005. Mineralogical reconnaissance of caves from Mallorca Island. Endins, 27, 131-140.

Onac, B.P., Effenberger, H.S., Breban, R.C., 2007. Hightemperature and "exotic" minerals from the Cioclovina Cave, Romania: a review. Studia UBB Geologia 52(2), 3-10. https://doi.org/10.5038/1937-8602.52.2.1

Onac, B.P., Sumrall, J., Mylroie, J.E., Kearns, J.B., 2009. Cave minerals of San Salvador Island, Bahamas. The University of South Florida Karst Studies Serie 1, p. 69. https://digitalcommons.usf.edu/cgi/viewcontent. cgi? article $=1002 \&$ context $=$ tles_pub

Pomar, L., Ward, W.C., Green, D.G., 1996. Upper Miocene reef complex of the Llucmajor area, Mallorca, Spain. In: Franseen, E., Esteban, M., Ward, W.C., Rouchy, J.M. (Eds.) Models for carbonate stratigraphy from Miocene reef complexes of the Mediterranean regions. SEPM Concepts in Sedimentology and Paleontology, 5, 191-225. https://doi.org/10.2110/csp.96.01.0191

Puşcaş, C.M., Kristaly, F., Stremțan, C.C., Onac, B.P., Effenberger, H.S., 2014. Stability of cave phosphates: Case study from Liliecilor Cave (Trascău Mountains, Romania). Neues jahrbuch fur
Mineralogie-Abhandlungen (Journal of Mineralogy and Geochemistry), 191(2), 157-168. https://doi.org/10.1127/0077-7757/2014/0254

Racovită, G., 1975. La classification topoclimatique des cavités souterraines. Travaux de l'Institute de Spéologie Emile Racovitza, 14, 197-216.

Rahman, A., Halfar, J., Adey, W.H., Nash, M., Paulo, C., Dittrich, M., 2019. The role of chitin-rich skeletal organic matrix on the crystallization of calcium carbonate in the crustose coralline alga Leptophytum foecundum. Scientific Reports 9, 11869. https://doi.org/10.1038/s41598-019-47785-2

Ransome, R., 1990. The natural history of hibernating bats. Christopher Helm, London, 235 p.

Serra-Cobo, J., Amengual, B., López-Roig, M., Márquez, J., Torres, M., Ripoll, A., Sánchez, A., Oliver, J.A., 2006. Catorze anys d'estudis quiropterològics a les Illes Balears (1993-2006). Bolletí de la Societat d'Història Natural de les Balears, 49, 89-107.

Serra-Cobo, J., Amengual, B., López-Roig, M., Márquez, J., Bayer, X., Guasch, C., Sánchez, A., Oliver, J.A., 2007. Quinze anys d'estudis quiropterologics a les Illes Balears (1993-2007). Endins, 31, 125-140.

Serra-Cobo, J., Bayer, X., López-Roig, M., Seguí, M., 2011. Les ratapinyades de les Illes Balears: Distribució, avaluació i estat sanitari de les poblacions. Endins, 35 / Monografies de la Societat d'Història Natural de les Balears 17, 269-282.

Snow, M., Pring, A., Allen, N., 2014. Minerals of the Wooltana Cave, Flinders Ranges, South Australia. Transactions of the Royal Society of South Australia, 138(2), 214-230.

https://doi.org/10.1080/03721426.2014.11649009

Tarhule-Lips, R.F.A., Ford, D.C. 1998. Morphometric studies of bell hole development on Cayman Brac. Cave and Karst Science, 25(3), 119-130.

Tuttle, M.D., 1975. Population ecology of the gray bat (Myotis grisescens): factors influencing early growth and development. Occasional Papers Museum Natural History University of Kansas, 36, 1-24.

Viles, H.A., 1984. Biokarst: review and prospect. Progress in Physical Geography: Earth and Environment, 8(4), 523-542.

https://doi.org/10.1177/030913338400800403 